Rhode Island College

Digital Commons @ RIC

Master's Theses, Dissertations, Graduate

Master's Theses, Dissertations, Graduate

Research and Major Papers Overview

Research and Major Papers

$6-29-2021$

\title{
"When will my reflection show who I am inside?": Queering Disney Fantasy"
}

Macie Lee St. Jacques

Follow this and additional works at: https://digitalcommons.ric.edu/etd

Part of the Lesbian, Gay, Bisexual, and Transgender Studies Commons

\section{Recommended Citation}

St. Jacques, Macie Lee, "'When will my reflection show who I am inside?": Queering Disney Fantasy"'" (2021). Master's Theses, Dissertations, Graduate Research and Major Papers Overview. 343.

https://digitalcommons.ric.edu/etd/343

This Thesis is brought to you for free and open access by the Master's Theses, Dissertations, Graduate Research and Major Papers at Digital Commons @ RIC. It has been accepted for inclusion in Master's Theses, Dissertations, Graduate Research and Major Papers Overview by an authorized administrator of Digital Commons @ RIC. For more information, please contact digitalcommons@ric.edu. 


\title{
“WHEN WILL MY REFLECTION SHOW WHO I AM INSIDE?”: QUEERING DISNEY FANTASY
}

\author{
By \\ Macie St. Jacques \\ A Thesis Submitted in Partial Fulfillment \\ of the Requirements for the Master of English \\ in \\ The Department of English
}

The School of Arts and Sciences

Rhode Island College

2021 


\begin{abstract}
$\underline{\text { Abstract }}$
In this thesis, I argue that the treatment and seemingly progressive representation of gender and queer identity in Disney films serves merely as a form of baiting to modern audiences, a baiting that suggests Disney wants to be understood as having embraced the ideas of progressive feminism and "homosexually-inclusive" ideologies, only to undermine and disavow them with a "bait and switch" narrative maneuvering that undercuts the film's ostensible message. I analyze and interpret the ways in which "classic" Disney animated features represent gender and sexual identity binaries through a close reading of Bambi (1942), Mulan (1998), and Frozen (2013).

I bring together Lacan's notion of the "mirror stage," the Symbolic order, and the idea that at the heart of identity lies a fundamental misrecognition, which leaves children especially vulnerable to the "hail" of ideology as it informs nearly the entirety of a child's headspace. Today, gender and sexual binaries are challenged at every level, and Disney seems to have embraced this progressive trend. Yet the lack of proper representation of LGBTQ characters and the negative subsequent treatment of those allowed to be seen in its films complicates this evolutionary progress that Disney claims it has achieved.
\end{abstract}




\section{Table of Contents}

Introduction $\quad 3$

Bambi: Animating Gender Fluidity 12

Mulan: Seeing a Reflection, or a Masquerade? 31

Frozen: Becoming a Queen 56

$\begin{array}{ll}\text { Conclusion } & 74\end{array}$

$\begin{array}{ll}\text { References } & 78\end{array}$ 


\section{$\underline{\text { Introduction }}$}

"I saw all the mirrors on earth, and none of them reflected me." - Jorge Luis Borges

Theorists have long argued for the importance of nurture and environment on a child's development. In his essay, "Social Cognitive Theory: An Agentic Perspective," Arthur Bandura explains that children learn through play and that as their brains develop and they take on the language of their primary environment, they establish rules for their imaginative worlds simultaneously. Those rules reflect the values at work all around them, taught to them by their parents, the kinds of reading they engage in, the games they play, and of course, the quality and quantity of their "screen time" (15). Chyng Sun documents this phenomenon in young children in her film, Mickey Mouse Monopoly, as kindergarten students play out the lyrics to popular Disney melodies on the playground, often while dressed in their hard-to-find Disney princess costumes. When children engage with Disney media, they perform the fantasies of their hidden desires as the films and their respective product tie-ins offer scripts and props that provide children fantasy narrative maps that structure their sense of identity, culture, and reality itself. "Pleasure...is a profoundly powerful pedagogue" (Sandlin and Garlen 26), and through this social practice informed by "pleasure pedagogy," Disney has cultivated its amassed social power.

Henry Giroux explored similar critical territory. With the recent success of its Frozen franchise, Disney's monopolization of children's entertainment shows no signs of slowing; indeed, corporate acquisitions have positioned the entertainment behemoth as the voice of social pedagogy. In his book, The Mouse That Roared, Giroux argues that early on, Walt Disney realized that social pedagogy was not confined merely to public schools but embedded in "the broader realm of popular culture." As such, Disney understood that popular entertainment functioned as a 
powerful "mechanism for the production of knowledge and values" (18), and it is through this, which children craft their social identity as an essentially ideological process.

Jacques Lacan argues that a child's first sense of identity or "self" stems from an initial misrecognition at the "mirror stage" of the young child's early development. When it sees its reflection in the mirror at this crucial stage, the child recognizes for the first time that the reflected image is not another child staring back, but a reflection of itself. But, Lacan maintains, because the reflection gives a false sense of wholeness and integrity, and because the image is onceremoved from the child, the mirror stage initiates the endless search for the satisfaction of fullness and wholeness that the mirror promises but denies. The reflection remains only as a projected fantasy towards which the child will shape its ego development, while always missing the target because it does not exist. The drive, however, remains as a desire in the individual subject to complete the circuit the mirror stage failed to close. Because of the misrecognition and incompleteness at the heart of the child-subject's ego-development, an unconscious need to achieve completion and wholeness in the eyes of the other (and in the eyes of the Big Other) informs the relationship between the child-subject and the Symbolic Order of culture, discourse, language, and all other social pedagogies. Lacan insists that the child's misrecognition of its reflection lies behind the child's constant comparison of its "self" - the misidentification of the "I" in the mirror — with " ego ideals" that the child-subject desires in the hopes of achieving the "ideal ego." The stuff of this ego-building process circulates in Lacan's Symbolic order, the realm of language, of entertainment, and all social pedagogies, including and especially Disney precisely because the corporation operates as an ostensible monopoly in children's culture and pleasure pedagogy. 
Disney's pleasure pedagogy has long facilitated a complementary ideology understood as "family values," all of which comprised a collection of ideologies that champion American triumphalism, binaries of good and evil, the obviousness of heterosexuality, and the fundamental binary of gender. Taken together, Disney's pleasure pedagogy serves as an example of how ideology functions as social practice learned in childhood. What I am focusing on is Disney's beginnings which, even now, continues to reinforce heteronormativity as the dominant social narrative. Indeed, Disney now agrees that the films produced during Walt Disney's reign, and up until the end of the twentieth century, reinforced culturally accepted representations of gender and sexuality while frequently representing racial, ethnic, and gender stereotypes in their films as a rule. Yet exceptions remain in the Disney canon. And later films of the "Second Golden Age," like Mulan (1998), suggest that Disney had become self-aware, and had now produced a children's animated feature that complicated and questioned gender as an "obvious" binary, and instead represented it as a culturally constructed performance that the hero or heroine must overcome — or embrace - to achieve success. It seemed that by the turn of the twentieth century, Disney discourse had evolved a more progressive message.

Since the 1990s, Disney narratives have presented characters as gender-fluid only to villainize or sanitize their gender identity. Consider the adolescent skunk, Flower in Bambi, and Scar in Lion King as only two examples. Flower, for example, must accept the higher social authority while "closeting" away his true identity, or worse, and more typically, as in the case of Scar, the queer-gendered villain is vanquished by the narrative's hetero-gendered "hero," Simba. Simba too makes a transition from his queer "step-parents" Timon and Pumba, back to heteroidentification when he returns to his father's kingdom. And yet, despite this disavowal of unstable gender identity, one cannot ignore the rising number of readably queer characters emerging in 
Disney's films. Confronting this subject in the "Part of Your World" chapter from his book, Tinkerbelles and Evil Queens: The Walt Disney Company from the Inside Out, critic Sean Griffin addresses the rising cultural impact, and the seemingly problematic nature, of portraying homosexuality on screen: "As homosexuality gains more and more public space, the homophobia of certain heterosexual individuals has increased exponentially. This message counsels not to fight irrational fear and hatred with more hatred but an attempt to ease the fears on both sides" (152).While some critics have argued for this interpretation of films like Mulan, Brave, and Frozen, to name only a few, in my thesis I am arguing that the treatment and representation of these themes serves merely as a form of baiting to modern audiences, a baiting that suggests Disney wants to be understood as having embraced the ideas of a progressive feminism and "homosexually-inclusive" ideologies, only to undermine and disavow them with a "bait and switch" narrative maneuvering that undercuts the film's ostensible message.

In the following chapters, I analyze and interpret Disney's representations of gender and sexual identity in key examples from essential films from Bambi (1942) to Frozen (2013). I bring together Lacan's notion of the mirror stage, the Symbolic order, and the idea that at the heart of identity lies a fundamental misrecognition, which leaves children especially vulnerable to the "hail" of ideology as it informs nearly the entirety of a child's headspace. Today, gender and sexual binaries are challenged at every level, and Disney seems to have embraced this progressive trend. Or has it? Over the next three sections, I analyze and interpret the ways in which "classic" Disney animated features represent gender and sexual identity binaries through a close reading of Bambi (1942), Mulan (1998), and in the third, Frozen (2013).

Beginning with Bambi (1942), my investigation will consider how Disney's “illusion of life" animated style explicitly dictates messages about sexuality and the body through its 
representations of nature and attempts to blur the boundaries between natural occurrences and those imposed by ideology. Derek Bouse comments on the heteronormative stereotyping of Disney's animal narratives, stating: "in nature there are virtuous, brave, and resourceful heroes, damsels for them to rescue or to win by their deeds, and villains who always pay the price of their transgressions. There is good and evil, right and wrong, punishment and forgiveness" (Griffin 43). Nature, it would appear, if we listen to Disney's "natural law," is as divided by binaries as our society. That is, of course, if we choose to believe that such occurrences are, in fact, "natural." This ambiguity between natural and constructed signifiers is further complicated in the film by the character Flower, a male skunk mistakenly labeled by a feminine signifier. What are we to do with this precious creature? Is he just a disruption in the "natural" order of Disney fantasy? Or a hidden nod to the queer community - itself a system of gender ambiguity and sexual confusion? My thesis will analyze examples in which the film represents the instability of the gendered signifier and how heteronormative society seeks to challenge and destroy the repercussions of its existence through the ending's climactic fire and Bambi's consequent coronation following it.

Such disruption in the "natural” order of gendered society reaches its apex in Disney's most ambitious attempt to represent the fluidity of gender and its performances in Mulan (1998) — the tale of a young woman who disguises herself as a man to take her father's place in the Chinese army. Unlike the other princesses in Disney's canon, Mulan is a specialty — serving as both a queer icon and Disney's first attempts at animating a legendary text rather than a fairy tale or novel. Her transformation in the film is equally symbolic as Mark Helmsing recognizes the pedagogical potential of reading Mulan as a queer character because "straight children do not need to learn lessons in transformation because they are always already endowed internally with all that is needed for happiness. It is the twisted, out of joint queer kids who need a transformation" (77). 
Many have praised Mulan for its feminist representations and values, yet question whether its place in the Disney canon a step was indeed forward for Disney, or a slide-of-hand to appease the rising demands for proper representation from its audience. In her essay "Disney's "Mulan"-the "True" Deconstructed Heroine?," Lisa Brocklebank analyzes how the film's portrayal of gender performance offers the possibility of a binary-fluid heroine, yet threatens, and potentially undermines, this same vision through its commercialization of the folktale's "marginalized and subversive form" (270). While Brocklebank recognizes Mulan's status as a cross-dressed woman to be one of social disruption, and a radical form of the transformation motif, she is reluctant to fully embrace the character as a fully-feminist icon, for although Mulan ultimately obtains a "hero's status," and overcomes the constraints of her gender, it is only achieved through her performance as a male, rather than the female character one would identity.

Brocklebank writes, "perhaps the only way for Disney to transcend [the ambiances of its gendered past] is to transcend gender itself—in effect, to literally make the heroine a hero" (272). Indeed, though Mulan breaks away from the overbearing femininity of her predecessors, her inability to enact agency except through her performance as a male certainly sours the feminist vision Disney appears to present, thus subverting the very possibilities it attempts to create. If anything, the film's failure to provide an ambiguously gendered hero-figure brings to light the interdependence of the very systems of gender and role-playing it seeks to deconstruct. Is Mulan truly the "deconstructed heroine" narrative that Disney audiences have craved? Or is she just another model with which mainstream culture can impose its social pedagogies on, thus reaffirming the very ideologies the film seeks to destabilize? Furthermore, is her position as a cross-dressing subject representative of a marginalized group of individuals, or merely Disney shifting its prescribed models of behavior to those more commercially beneficial for its margins? 
My thesis will further examine the potential of reading Mulan as queer and question the lessons which Disney attempts to teach through such a culturally marginalized lens.

The final leg of my investigation will explore the apparent "leaps" made by Disney's "cultural transformation" over the past decade as a new "revolutionary-style" of princess has slowly emerged to satisfy the displeased critics of its former female leads. The new Disney princess seems a more feminist rendition than her predecessors: she is brave, self-reliant, and even more shockingly, not interested in finding 'true love.' However, a closer look at these "feminist" princesses reveals that Disney has not embraced a new form of the female protagonist at all. Instead, these new agentic princesses are simply a distracting illusion of feminist values while Disney continues to broadcast the same traditional gender representations of its past. Cole Reilly comments on the potential dangers, and admitted joys, of the evolutionary development of the Disney Princess franchise's representation of empowered feminization in his essay, "An Encouraging Evolution Among the Disney Princesses?" as it positions children as both the crafters and consumers of pedagogical socialization: "Disney wants to generate products that children will want to consume, but perhaps they sell children short of their estimations. Maybe they don't realize that children want more - that the Meridas of the world might in fact have a better pulse of what is in their interest than the Elinors among us" (60). It is no secret that children and young adults control the sway of mass media, everything from magazines to movies to fashion and everything in between is dictated by what is considered "popular" by the youthful demographic. Seeding themselves into the conscious of children early in their development, Disney is able to keep themselves rooted in a positive position within this sphere, thus granting themselves a prime space to regulate and respond to the very consumers which uphold their power as a pedagogical agent of social culture. 
The most successful example of this tactic is Disney's Oscar award-winning film, Frozen (2013); a rendition of Christian Anderson's fairytale, “The Snow Queen.” In the movie, Princess Anna of Arendelle, must find her sister, Elsa, the Snow Queen, and save their kingdom from eternal winter. Kept within the palace walls all her life, Anna dreams of meeting her 'true love' and escape the confines of her home. Although her primary objective in the film is to find Elsa and restore the emotional bond they had as children, Anna's desire for "love at first sight" embodies the traditional feminine values of love and marriage that Disney has advocated for years. Elsa, on the other hand, is marked as the social outcast of the film by her ice powers. A victim of emotional abuse, Elsa's father, the King, teaches her to fear her abilities and repress any desire she may have to use them. This repression of Elsa's powers suggests that the King is following the regulation of social values by punishing Elsa for being abnormal, as her powers do not fit the feminine expectations of a woman, or more importantly, a future Queen.

In the tradition of the fairytale, Elsa's position as a marginalized "outsider" grants her the ability to see the world with "clarified vision"- a view where she is free to observe and comment on the world outside of society's influence (Brocklebank 269). While critics such as Brocklebank will recognize Elsa's role as the film's "outsider" as an opportunity for agentic narration and deconstruction, though admittedly, one that is never allowed to fully blossom into fruition, Reilly questions the necessity of subjugating Elsa in the first place. In praising the film for its denouncement of the 'true love' motif and a consequent ending of marriage, Reilly notes that "Elsa herself never expresses any need for romance of her own. One might imagine any number of reasons why this is the case, but I, for one, am relieved that it does not get an explanation, because it doesn't need one" (60). With the release of its sequel, Frozen II, many fans were quick to comment about Elsa's sexuality after her lack of romantic interest in the first film. Is she the lesbian 
Queen audiences have been waiting for? Or is it a trick to "bait" audiences into attending film screenings, hoping for a glimpse of evidence to either confirm or deny the very identity which Reilly claims is “unneeded.” Perhaps it is so; maybe Elsa's sexual ambiguity is an unnecessary factor in the overarching narrative of the films. But even so, one cannot help but envision the possibilities for representation that it allows. My thesis will examine key scenes from Frozen to demonstrate how Disney films have evolved, yet in the end, continue to disavow non-binary and homosexual representation. 


\section{Bambi: Animating Gender Fluidity}

With its anamorphic animals and their world of Nature and morality, the beast fable has existed as a staple of children's literature for centuries. However, its adaptation into a new kind of animated film, Bambi, was met by critics of the film industry at the time with doubt and anxiety. MGM had passed up on the possibility of turning the popular book into a film. The task of anthropomorphizing the animals was simply too difficult, the risks too great. Instead, MGM sold the rights to Walt Disney and Disney jumped at the chance, including it in the short list of Golden Age Disney films from 1938-1942. Representing Nature on film so that the viewer recognizes it whether or not it appears to be "natural" - depends on the anamorphic perspective of the animated image. As Žižek explains, anamorphosis is a phenomenon in which an object, when looked at straight-on, "appears as a meaningless blotch." It is only once "we shift our position and look at the picture from an angle" does the object "take on the contours of a known object" and become identifiable (68-9). There is an accidental quality to the anamorphic perspective, as well as a highly calculated effort to create the desired visual effect. Both are true in Bambi through Disney's anamorphic representation of Nature and its forest of anthropomorphized animals.

According to critic Kimberley Reynolds, a scholar of children's literature and culture, the power of children's animal narratives to blur the lines between fantasy and realism threatened a child's comprehension of the world around them, as the genre requires writers to render the thoughts of animals into human language. In this way, children's entertainment already assumed a kind of anamorphic representation of reality, stepped-down to a child's level, to be seen from their perspective as far as an adult can determine it. "There was anxiety about such fantastical devices," she writes, "on the grounds that consumers of children's literature might have a difficult time distinguishing fact from fiction if too heavily exposed" (81). With animal stories being 
published yearly, how will children know the difference between what's real and what's not? All of this reasoning presumes that the real world is in fact real and not a fantasy itself. In part at least, Reynolds' argument is a kind of puritanical over-simplification while on the other hand, offers a telling example of understanding Althusser's notion of ideology as an "imaginary relationship" to the "actual conditions of material existence" (Žižek 77). Disney’s anamorphism was a distortion of an already distorted representation. What Althusser calls ideological interpellation Lacan explains as the "mirror stage"- that point in human development that children take on their identities, singular, based in the world represented to them via what Lacan calls the Symbolic order, which to the child amounts to the adult world. Children's fantasy helps the child negotiate this gauntlet, theorists have argued, while others acknowledge that environment plays a determining role in identity formation.

The representation of Nature almost always plays a prominent role in children's literature. Beginning with Aesop's Fables, the tradition of literature for children has linked Nature, and its anthropomorphized, "anamorphic" animals, to qualities and ideas that adults, in turn, link to children and childhood. The stories adults tell children depict Nature as an idea linked to freedom, innocence, the "time before," a green world. In that world of fantasy, peril and adventure exist. In it lives times (and places) where children may act out adventures and explore life without the constraint of adult influence. Children, experts often claim, "naturally" gravitate to the beast fable because in these stories, they see characters facing the same kinds of struggles as they do. From The Jungle Book to Winnie the Pooh, animal symbols encode how the child should "imagine" Nature and always without fully understanding the underlying ideological connotations. In the beast fable lies a primary example of ideological interpellation and how it occurs in childhood, and how the symbolic codes of cartoons colonize the child's imagination. 
As Reynolds explains, we believe "children relate to domesticated animals because they are [also] weak, nonverbal, and powerless in relation to adults" (81). Since the early days of literature for children, e.g., the Brothers Grimm and Lewis Carroll, this supposed empathy between child and animal representation has maintained animals' presence in children's literature, transforming it into a staple of the genre. In "anamorphic" beast fables, narratives inhabit a moving boundary line that separates fantasy representations of animals and realistic representations that are both an example of Nature as a major trope in terms of what is supposedly "natural," or "true to life." At the height of Walt Disney's push to realistically represent Nature in an animated feature film comes Bambi (1942), the 'coming-of-age' beast fable of a young fawn who grows up to take his place as the "Great Prince of the Forest."

Nature, in terms of my analysis, refers to "the phenomena of the physical world collectively, including plants, animals, the landscape, and other features and products of the earth, as opposed to humans or human creations" ("Nature," def. 11a.). In short, Nature is the term we use to refer to the entire network of organic and inorganic systems on Earth and beyond. Curiously, since humans lack the ability to communicate with Nature, we have excluded ourselves from Nature, for it is an "other" and set in opposition to human subjectivity. The misrecognition of Nature as "other" informs the ideological fantasy of original Nature as a virginal, untouched place. It is set off against Man's brutality and serves as a symbolic reminder of the lost Eden and the heavenly bliss that Man has forfeited to bloodlust and greed. Nature in Bambi appears as a fantasized version of the "real" world, and the "natural" representations within the beast fable serve to link ideology to the material world it represents. However, the gap between Nature and "natural" remains permanently open, and hence, the dialectic between Nature and "natural" in Bambi is an oscillation between one order of fantasy and another. 
In Lacanian terms, Nature-as-Eden is an example of the l'objet petit a', the "other" that serves as an object, and simultaneously, the cause of desire for the object in question. We desire the object because it seems to hold "that something" that makes an ordinary object sublime" (Žižek 66). As is common, we desire what we feel we have lost. In this case, Nature-as-Eden becomes the site of our longing for the lost world of innocence, of childhood. Bambi then offers itself as an object $a$ ' to substitute for the thing that we can never recover, Nature itself.

Complicating the object-cause desire one has to the object-cause of desire is what Lacan calls "misrecognition." Misrecognition and misunderstanding are "built in" to the world of signifiers and symbolic orders. Nature and its "natural" representations can be understood then as subject to anamorphosis. So the problem with representing Nature is at least two-fold. First, signifiers can only provide an approximation of Nature, not Nature itself. It is always hidden from view by the very medium that sets out to depict it. In order to understand and experience Nature, we must put the information we gather from observing Nature into language, all of which is subject to ideology, that is, "anamorphosis." In this way, ideological representations of Nature in Bambi serve as an example of the ways in which popular entertainment reinforces one's tendency to misrecognize our dilemma vis-à-vis Nature. At best, we perceive only constructed projections of Nature, while the "natural" representations of the forest and its animals in Bambi reinforce, for example, the notion of gender as simply "natural tendencies" or "inborn or hereditary characteristics."

By actively engaging in the representation of Nature, "natural" and the anamorphic misrecognition of fantasy, Bambi serves as an example of how the social order functions and interpellates individuals into subjects through ideology. The film's representation of Nature and as "natural" informs the social practices of the anthropomorphized animal characters as well, 
which is precisely why understanding how Nature's "natural" function reveals the film's conflicted messaging around representations of gender. Bambi both complicates even as it attempts to reaffirm "natural" notions of gender, and what it means to be either male or female even as the film conflates the idea of Nature with the idea of "natural." The confusion of these two terms structures the film's message of how "nature works" in a fundamental misrecognition. This is how ideology functions.

In the film narrative, Bambi's trials and tribulations are analogous to the experiences of childhood. Whether children identify with Bambi or not, they are certainly encouraged to by the way the film represents his birth, growth, and development. Before our eyes he learns to walk, speak, and socialize with the other animals; they live like we do, with distant fathers whose presence in the film is felt only by the rules they pronounce on their children. Bambi learns who his equals are and the hierarchical power relations between adults and children, and between animals. Thumper, for example, is the recipient of numerous reprimands from his father via his mother in the form of, "what did your father tell you?" The big Other intervenes at the child's mirror stage and introduces "the name of the Father," or "the Law," as Lacan would say — the power that sustains the Symbolic and the social practices it contains. Only through the Symbolic can Thumper succeed in becoming a "good subject," willing to face the "normal" responsibilities of adulthood. Lessons of politeness come with other more important content: ideology as cisgender identification, heteronormative values, and the "naturalness" of gender as a binary, and stereotypical gendered animals as "natural."

When Walt Disney set out to produce the film in 1939, his goal was to represent the source material as realistically as possible. Disney famously had live fawns delivered to the California studio from Maine — named Bambi and Faline, respectively—and even had an artist spend six 
months sketching forest scenes in Baxter State Park (Lutts 163). In an interview following the film's release, Walt expounded on what he saw as his responsibility to render Nature ever more "naturally" as his technological powers grew. "In Snow White, we had cute little animals, more on the fantasy side. In Bambi, we had to get closer to nature" (Smoodin 56) precisely because the source material, Felix Salten's beast fable, seemed to require it. The challenge almost proved too great due to the labor cost of drawing realistic forests, among other elements.

The animals of Bambi exist within a community, complete with hierarchies, power relations and prescribed social practices. Pedagogically, Bambi's world is hardly different from that of the child viewer. Bambi's community is comprised of nuclear family units: children play and learn together (despite prey-predator relationships), mothers nurture and protect their young, and fathers maintain order from a distance through "the voice of family authority" (Payne 140). The fact that the film at once represents "family authority" as "patriarchal authority" is ideological because it is assumed by the narrative. No other alternative is espoused by the film narrative, at least not consciously. The underlying ideology which the film perpetuates mirrors that of traditional patriarchal structure; females are the submissive subjects of domesticity while male power-specifically, that of "royal authority" — rules all. There is no conflict in Bambi's forest; predation does not exist, and all animals are satisfied living under the sole authority of the "Great Prince of the Forest." There is no contestation for power or deviation from the "status quo"—all animals live, perform, and comply with their gender roles' expectations. The more significant conflict of the narrative is the dichotomy between that of Nature, coded as the feminine subject, and Man who has invaded and ravaged her forest.

Critics have commented on this before. David Payne insists that the film's "realism of nature ... is overwritten with a scripted drama in which nature, and its conventional alignment 
with the feminine, is occupied by a patriarchal social system that is the fullest perfection of Man's wish: a single male patriarch with absolute dominion and property ownership of all that transpires in society" (144). Patrick D. Murphy asserts that the "iconic masculinity of Bambi [offers] ways of seeing and telling the story of domination as the natural social order. Nature's story, rewritten in Man's language, becomes a story of contest, sexuality, and war" (Bell, Haas, \& Sells 11). In Bambi, Nature functions as another feminized character of the narrative who experiences "Man" as a repressive, violent force. While this theme is consistent with Felix Salten's novel, Disney adaptors remained at odds with the messaging of the story. In the ongoing conflict between Nature (as Bambi lives it, and we with Bambi) and Man (gun-carrying invaders intent to kill and destroy) we see Nature diminished by the brutality of Man's brash aggression through the death of her wildlife at the hands of their rifles, the destruction of her foliage by their fires—only to rise and restart with the warmth of Spring. It is an ongoing cycle of brutality and submission, aggression and forgiveness, and it is through this conflicting dichotomy of femininity and masculinity which we watch the young Bambi grow and develop into his position of absolute authority. Because of this, in Bambi we get no closer to the truth of nature, or what is natural, but only ideological, especially in terms of gender.

At its heart, Bambi is a coming-of-age story, a classic bildungsroman told in the person of a deer, from fawn to buck. His birth is a spectacle for the forest as the "young prince" has finally arrived, ushering in a new generation of royal authority in the forest. Nature, the narrative insists, is a monarchy. Primogeniture rules the land. Birds and other woodland creatures flock to where Bambi's mother is nursing him in the brush - all of this overseen by Bambi's distant father, the "Great Prince of the Forest." He deigns to watch the spectacle from his distant, even alienated, place atop a nearby cliff. Curiously, though the animals of the film all recognize that Bambi is a 
boy, the realism of Bambi's depiction has traditionally confused audience members who mistake the fawn for a girl. David Payne describes his own reaction to his daughter's (at the time, of age two) identification of Bambi as a fellow girl: "In that moment, I was struck that Meredith had no cultural training that would prevent her from expecting that the newborn fawn would be, like her, a female child. I wondered ... when she would learn and whether she would react to the realization of Bambi's gender" (146-7). As a newborn, Bambi fulfills the traditional model of femininity that the film exhibits later on. He has a dainty body, long eyelashes, and exudes fragility as he "wobbles" his way around. Bambi needs to be taken care of, just like a girl. Even his name is a female signifier as "Bambi" derives from Italian and translates as a girl's name meaning "small child." While Bambi's coming of age is into a heteronormative binary world, the unconscious material from Salten's book and perhaps the adaptation process itself, leads to a number of symbolic disruptions in the film's gendering thematic.

Regardless of how the child initially genders Bambi, children's literature critic Charlotte Huck argues that what is most significant about their visual introduction to the young fawn is that they are at least able to recognize some aspect of either gender in the character. She writes, "characters have to capture the essence of femininity and [or] masculinity, or children will have a difficult time identifying with [them]" (Leher 6). Gender, insists Huck, is deeply rooted in the child's sense of identity. In order to visually internalize the world around them, children must first be able to recognize gender as a signifier. Without gender to function as a means of regulation, the child becomes "confused," thereby threatening their understanding of the world. And yet, Bambi disrupts this model through his appearance's fluidity, leaving viewers to form their own conclusion about his gender until the film's narrative reveals it. On the one hand, viewers who see Bambi as a female demonstrate an unconscious recognition of the semiotic codes which have become 
synonymous with femininity and label the young fawn accordingly. On the other hand, to consciously accept Bambi as a male presents gender as a system of overlapping signifiers that cross, divert, and even androgenize traditional masculine and feminine models. Thereby suggesting that gender is not a fixed set of "natural" signifiers, but a system of semiotic codes linked to the child's development through social conditioning. In either case, ideology is at work.

A similar phenomenon occurs in human birth. When babies are first born, doctors immediately look for the infant's genitalia to identify their gender. This identification proceeds a lifetime of signifiers and expectations: male or female, blue or pink, masculine or feminine, and so forth until the child has established an identity based on social practice (cultural discourse) integrated into their own subjugated identity. Before the mirror stage, it could be argued that the child is essentially without gender in spite of any outward biological signs. In this state, the child is undifferentiated in the gender binary. Different cultures have initiated the indoctrination of gender binaries at different times in childhood. It was not uncommon for boys to be dressed as girls through their toddler years during the Victorian and Edwardian periods. Once the child's gender is confirmed at the appropriate time, a plethora of ideologically informed social practices inform the child's developmental environment. Bambi represents a self-conscious attempt to appeal to parents and children in 1942 with wholesome, family entertainment that was brave enough to tell "dark truths" about death and loss. Meanwhile, the film invites misrecognition of Bambi's gender before he is confirmed to be a boy. While all about gender, the film accidently finds itself questioning the very nature of gender and representation. His "natural" birth as a boy functions as an expression of ideology and so undermines the notion that gender refers to some inborn "essence" of a person. He is simply a fawn until we find out his gender, then he becomes a subject in which we can attach our notions of what it means to be male and female and critique his 
actions and behaviors accordingly. The film attempts to naturalize the identification of gender when at the same time it implies gender is itself a construction of social practice.

The first deer that Bambi meets is the young doe, Faline, at the pond following his entrance into the meadow - the epicenter of communion for their species. Bambi misrecognizes her reflection as his own; startling back in surprise as she laughs at his confusion. At this moment, as Bambi is standing next to Faline, we see Bambi's previously hidden masculinity. Faline is slimmer, with lighter markings and bright blue eyes surrounded by long lashes. Her movements adhere to the traditional notions of femininity; she is graceful and calm, not wobbly and sporadic like Bambi. Though Faline is a feminine figure, she too complicates the film's messages of gender. Bambi is timid and wary of the world around him; Faline is much more adventurous and "forward," even assertive. She is the one to initiate contact and play with Bambi, going so far as to kiss his cheek while he hides behind his mother in fear. Even her name denotes a sense of authority, as "Faline" comes from the Irish tradition meaning "in charge." As Bambi's future mate, Faline's name is a clever nod to the patriarchal restoration and heterosexual reproduction they will undergo. Nevertheless, one has to question why she is the dominant member of their relationship in their courtship and not Bambi?

At this stage in the film, Bambi and Faline are still fluid in and as much as they are flipped versions of gender norms. They have not fully integrated the lessons and messages of the social order but are beginning to learn. A telling example of this occurs when Bambi and Faline observe a group of bucks sparring in the meadow. Excited by this new form of "play," Bambi charges at Faline, only for her to flee in fear while he looks on in confusion. Though Bambi stays to watch the other males, this moment demonstrates how children learn by mirroring adults' actions. While Bambi, in his tender age, does not understand the connotations of what he is doing and seeing, the 
film suggests that he is acting upon his "natural instincts" by performing these masculine roles. His confusion at Faline's fear suggests that he has not cognitively formed a clear understanding of boys' and girls' specific behaviors and actions, developments that will appear as he continues to mature.

Bambi represents childhood and adolescence as a time of gender flux. The instability of the film's gender signifiers is further developed in the character "Flower"- - a kit (or child-skunk) mistakenly named "Flower" by Bambi because he met the kit in a field of flowers while Thumper served as interlocutor for the wide world. Curiously, Thumper's channeling of the Symbolic Order, his father's Law, and his family upbringing lead to Bambi's misrecognition of the baby skunk. While Thumper, the honed subject of ideology in the threesome, laughs at Bambi's mistake, Flower appears pleased by the name, "Oh, that's alright. He can call me a flower if he wants to. I don't mind." His response is bashful and feminized as he shrilly giggles and blushes into his tail. Flower holds a unique position in the Disney canon as the first gender-fluid character to appear in a feature-length film. At first, his gender is ambiguous to the extent of being coded androgynous. Flower is a heavily feminized male character with eyes and lashes like Faline's and a shy and sensitive personality depicted as stroking his fluffy tail and coyly blushing over his shoulder. He is a representation of a "naturally" feminized maleness. Like Bambi, Flower invites gender misrecognition-yet unlike Bambi, Flower's gender is not as quickly codified into the masculine. While maturity brings his friends a much more muscular form, Flower's only indication of being a male is his deeper, baritone voice. Aside from this, Flower still maintains his fluttering lashes and sleek appearance. Furthermore, while Bambi's feminine name is given at birth, Flower's is simply a childhood nickname, and to a larger extent, a misrecognition of his gender, which he claims as his name and, apparently, his identity. Even in hibernation, a fatter Flower is shown 
being awoken by Bambi and Thumper explaining, "all us flowers sleep in the winter" before returning to his slumber.

In naming him Flower, Bambi appears to have struck a hidden chord within the young skunk, which seemingly permits Flower to behave in this feminized manner that correlates with his appearance rather than his biological gender. One can argue that this moment of misrecognition, like Bambi's experience at the pond when he sees himself and Faline in the water's reflection, is a moment of discovery for Flower: by accepting his new-found position as a "feminine" subject, Flower takes up the position of "queer subject," and the film seems perfectly willing to make this "queer" space for him. This is an exceptional moment for Flower, and queer audience members, as Bambi—the future ruler of the forest and figure of authority—is essentially giving Flower his blessing to be who he is, rather than what he should be. However, while this reading can be easily undermined by Bambi's age and the fact that this moment is to be read as a joke in the film, viewers who fall within the same vein of sexual ambiguity as Flower would most likely disagree. Regardless, one cannot help but imagine the potential of Flower's character and this lifestyle of genderfluidity—had he been allowed to continue it.

With Spring comes the inevitable time of "twitterpation" in which all sexually mature animals' pair off and mate with the opposite gender of their respective species. Friend Owl, the old, wise overseer of the forest depicts mating as something to be feared and avoided: "It can happen to you, and you-[pauses at Flower until the skunk points to himself]. Yes, even you." While Bambi and Thumper are disgusted by Friend Owl's tale, Flower is terrified. Considering Flower's evidently "queer" position, one can argue that his fear is one of sexual repression —now that Flower can be clearly identified as a male by his voice, he too must adhere to the same 
masculine expectations as his friends. Though still addressed as Flower, the adult skunk must now fulfill the obligations of his gender, responsibilities which he had alluded throughout his childhood.

Immediately after making a pact with Bambi and Thumper to never fall in love, Flower catches the eye of a female skunk—oddly enough—plucking off the petals of a flower in a game of "he loves me, he loves me not." Sensing a potential mate, the female skunk beckons Flower with her "feminine" behavior, alluring him with her musical laughter. As if in a trance, he is left staring into her sensual blue eyes. For a moment Flower is frightened and unsure at this meeting only to stop short when she kisses him. Flower's reaction to his first kiss is one of obvious phallic imagery: he stiffens, turns fully red, and then falls over with a sigh after the act is complete. Lasting only a few seconds, the scene symbolizes the moment of sexual development and awakening as Flower fulfills his masculinity by "mating" with a female. As the film's potential homosexual character, audiences must have sighed in relief as the young skunk finally finds the proper way to be a boy. In stripping the physical flower of its petals, it appears that the female skunk has also metaphorically stripped Flower of his queerness, thereby solidifying his place in the social order and establishing his traditional place in the gender binary. Flower's uncertainty is gone, and he quickly follows his new mate through a field of daisies, leaving his childhood friends behind with a laugh and a shrug as if to say, "what are you going to do?"

However, that is a substantial question: what are we to do with Flower's mating? Are we to read Flower as a gender-fluid character, disavowed and repressed by the film's heterosexual ideology? Or is he a representation of a "confused" child, one whose upbringing never truly established a defined set of roles and expectations for him to follow, like Bambi and Thumper's, and has now in adulthood learned how to behave? At the end of the film, Flower greets Bambi's newborn twins with his own son, named Bambi after his childhood friend. By naming his son with 
a feminine signifier, Flower grants his child the same opportunity for genderfluidity that Bambi had bestowed upon him. In this way, Flower may continue his legacy of "queer identity" while also maintaining an appearance of heterosexual compliance through his offspring.

This act of "muted rebellion" is precisely what Eve Kosofsky Sedgewick describes in her essay, "The Epistemology of the Closet," in which she states that queer individuals act through a duplicity of identity - an outer performance that adheres to the rules of society, and the hidden inner identity we keep closeted away. While those in the closet conform to society's behaviors, in this case, that of heteronormativity, they still maintain their sexual freedom in secret, thus granting them the ability to express their true selves without fear of being "outed" to the world. By naming his son after Bambi, it stands to reason that Flower is not only honoring his friend but the person who helped him discover and craft his identity through that fateful misrecognition.

Bambi and Flower eventually surrender to the social order, but there is another questionably queer character in the film which maintains his sexual ambiguity throughout, Friend Owl. A close friend of the royal family, Friend Owl demonstrates his authority over the other woodland creatures of the forest as they quickly disperse in fear when he commands it. He is the only owl and, more significantly, the only predatory creature. While the other birds twitter away their endless love songs, Friend Owl remains mate-less as he warns Bambi and his friends against falling in love. Bambi's forest demonstrates that it resigns within a strictly heterosexual sphere. As the film's appointed "love expert," Friend Owl should certainly uphold this view and encourage the young animals of the forest to participate in it, yet he finds the idea of love revolting. Considering Friend Owl's position in the film, his disdain towards mating presents an interesting question: is Friend Owl merely a lonely bird, angry that the film has left him without a potential 
mate? Or is his resistance towards the heterosexual matrix another example of the film's attempt to disrupt the "natural order" of Bambi's forest?

I propose a theory: Friend Owl is not merely a mate-less bird, but a bird who lacks the desire to mate. What comes across as a disbarment of love may be Friend Old masking that he is incapable of sexual love. In short, I believe Friend Owl is asexual. According to the official Disney website, Friend Owl's canonical name is "Wise Old Owl." Though male, he is not addressed in the traditional titles of "Mr." or "Sir" like the other animals. Instead he is labeled "Friend." This androgynous titling of his character signifies a sense of sexual lack within him in a similar manner to how Flower's childhood nickname signifies his heavily feminized identity. The film further complicates this theory when Friend Owl interacts with Flower. During his lesson on love, Friend Owl warns Bambi and Thumper that it could happen to either of them before pausing on Flower. He studies the young skunk as if he is internally questioning if Flower is genuinely in danger. This moment of hesitation could suggest that Friend Owl recognizes Flower's queerness and must pause, in fear that he may "out" the young skunk to his comrades. Friend Owl only confirms his suspicions about Flower's "endangerment" once Flower points at himself, gulping in fear. In waiting for Flower to make the next move, Friend Owl aligns himself as an ally to the younger queer character, suggesting a moment of bonding and understanding between the two.

Although the film quickly places Flower on "the proper path", one cannot ignore this moment between the elder owl and the young skunk for it hints at a relationship the film is not ready to accept — that of queer community. As gay rights activist and author Mark Helmsing states, "In the closeted world of our childhoods, we have learned early on that attaining the prince is not in our cards — society will not allow that to happen — and so we must forge other, queered attachments" (75). Heterosexuality is presented as the only option for sexual orientation 
in the social order of the film. To have two signified queer characters share a moment of understanding suggests that just like in our society, homosexuality and asexuality exists, albeit in softer tones. The fear of discovery leaves these individuals with few options: either convert and remain repressed or be yourself and face the consequences. There is no violence in Bambi's forest except for Man's intrusion, the animals themselves are peaceful creatures. What, then, is the penalty for challenging the social order? Loneliness. Without a mate, Friend Owl resigns in an outcasted position: he is below the royal family, yet above the other animals. He is respected and feared yet lacks love and understanding. Because Friend Owl serves the social order, the film allows him to remain mate-less and offers the role of teacher in exchange. In this position, Friend Owl may help others navigate the obstacles of society's sexual expectations, all while keeping a scrutinizing gaze upon Nature and its operations.

Bambi's Nature is a duplicity of fantasy and ideological order: it offers a feminized Eden in which Man invades and conquers its natural peace with its own patriarchal expectations for gender. While its anamorphic animals provide a spectrum of examples in which these gender roles are both challenged and affirmed, the film ultimately sides with that of the Law-the word of the father. The death of Bambi's mother contests to this loss, as the young fawn grows and develops under his Father's lessons. The loss of his mother, his sole source of nurturing affection and information, marks both Bambi's departure from childhood and his subsequent interpellation as a subject in the patriarchal society of which he will one day rule. Her death occurs near the end of Winter, a time of rejoice at the prospects of Spring and the rejuvenation it promises. Though shot off-screen, the connotations of the fatal shot ring throughout the forest. The camera pans out as the young Bambi scrambles through the snow shouting, "Mother!" until he comes face to face with his father. The Great Stag's command "come"-following the death of his mate and mother of his 
heir-hails Bambi into the womb of ideology, and it is here where Bambi is nurtured and reborn into the world of manhood and authority.

Except for Bambi's mother and Flower, males and females are coded in the film by their eye coloring: brown for males, blue for females. Bambi has the same brown eyes as his parents while Faline has the stereotypical blue eyes of a Disney maiden. This distinction between Bambi and Faline is important because during the second half of the film, Faline's eye color suddenly changes to brown as she is attacked by the hunting party's hounds. This discoloring does not merely occur in one or two scenes but the entire six-minute sequence in which Bambi must aid in her rescue. Combined with her mature appearance, Faline is visually identical to Bambi's deceased mother, even mimicking her cries for him after being separated by the chaos of Man's return. Walt Disney was known for being incredibly meticulous when it came to his animated endeavors. Every scene underwent his critical gaze before it was deemed suitable for the big screen, and even then, Walt was reportedly never satisfied with the outcome. Such attention to detail is precisely why this minor flaw in Faline's coloring suggests that it was not simply an accident.

Matching Faline's coloring to Bambi's mother demonstrates the effects of her death on Bambi's development. As a fawn, Bambi was unable to save his mother from Man. Now that he is older, Bambi has the chance to save his mate from the same fate as his mother, tapping into the oedipal connotations of their relationship. For Freud, the Oedipal complex occurs when a boy symbolically fights his father for his mother's affection. However, since the father prevents the child from a sexual relationship with the mother, it creates a sense of lack in the child that they attempt to fill with other desires. But because desire can never be satisfied, argues Lacan, the child instead enters the world of signification and begins a life-long journey to craft a sense of identity. With his mother "unable to be with him anymore," Bambi is thrust from the loving sphere of her 
influence and must now face the dangerous world from which she had protected him. As Joseph Zornado explains in his book, Disney and the Dialectic of Desire, "The death of the mother represents the precise moment of interpellation by the big Other in the form of the Symbolic, that is, the moment when the Father and the Law interposes as if to take over where the mother had left off in order to guide Bambi towards his patriarchal fate as prince" (134). Bambi's father emerges from his isolation to care for his son and teach him the ways of manhood and, more importantly, how to be a ruler. As Bambi matures, his initial love for his mother transfers to Faline as she becomes the new desired object of his lust. Just as his mother had protected him in childhood, Bambi's entrance into manhood prepares him to fulfill the same role for Faline, ensuring their courtship and the potential offspring their future positions as prince and princess will demand.

When Man invades for a second time, Faline becomes trapped by their hunting hounds as embers from Man's fire ignite the entire forest. Bambi comes to her rescue, heroically fending off the dogs as Faline runs to safety. A bullet from off-screen hits Bambi in the leg, leaving him wounded as the fire continues to spread around him. His father, the Great Stag, rushes to Bambi's side and pushes him to safety, “Get up! You must get up!” Together, the two bucks escape the fire, mirroring their last escape from Man when Bambi was a fawn. Unlike the first incident where Bambi was weak and unable to protect his mother, Bambi demonstrates his strength and his internalization of his father's lessons by fighting his way out of Man's clutches, proving that he has grown into his role. His successful rescue of Faline is thus a two-fold contestation: a triumphant entrance into manhood and the fulfillment of his gender by proving himself a proper mate. The lingering embers of Man's fire destroy Bambi's forest, symbolically destroying the sphere of childhood innocence and freedom of Nature that Bambi has grown 
within. With Faline safely by his side, Bambi stands in the ashes of the forest as a man, ready to finally surpass his father and become its new ruler.

Spring returns and we see Bambi at the height of his masculinity: Faline, with blue eyes, has given birth to twins as Bambi oversees them from the overhanging cliff, his father by his side. With this, the former "Great Prince" nods to his son before stepping out of frame, suggesting that Bambi has now taken over as the new prince. The circle is complete in an idealized vision of nature, the likes of which will inevitably follow the same patterns of ideology and gender roles that its previous generation had taught the newer. Though the disruption of gender will continue to be symbolized by Flower, soon to be carried on by his son, Bambi, Disney will refrain from presenting a positive representation of genderfluidity until the release of Mulan (1998). 


\section{Mulan: Seeing a Reflection, or a Masquerade?}

While the androgynous nature of Flower has been a source of comedic joy for some audience members — and simultaneously for others, a concern — he is not the first queer-coded character to appear in a Disney animated feature. Disney films have been in a coded dialogue with the LGBT community from the beginning. Sean Griffin, author of Tinker Belles and Evil Queens: The Walt Disney Company from the Inside Out, argues that even in the studio's earliest days, audience members could discover queer narratives in their beloved films if they chose to read between the lines. Following his debut in 1928, one of the first advertisements for Mickey Mouse presents him happily plucking a harp as the poster proclaims: "Always Gay!" The whistling, dancing mouse quickly blossomed into a gay icon in the 1930s as "Mickey Mouse's parties" began in Chicago where, according to Griffin, members of the then largely invisible LGBT community could safely mingle together without fear of being outed or of facing physical harm. It was not long before gay men began using "Mickey Mouse" as a coded phrase signaling their sexuality to other community members while remaining "closeted."

In her essay, The Epistemology of the Closet, Eve Kosofsky Sedgewick argues that the state of being "closeted" represents a duality of identity: the "accepted" outer performance we perform for society and the "forbidden" inner desires we keep hidden away. The duplicity of the "closeted" subject persists in Disney animated films as a figure of disruption even as it serves to affirm heteronormative social practices ostensibly. As such, Disney's queer characters must learn to normalize their eccentric personalities at the very least, and at best, they must find a way to make their queerness beneficial to the moral authority of the filmic narrative. Only then, the film narrative reassures us, may they finally integrate into society as a fellow member of the social order. If not safely integrated into the symbolic order of the film narrative, queer characters are 
"closeted" away, or worse, suffer destruction by the narrative's "heroes." Yet, according to Sedgewick, this moment of erasure is when Disney's queer subjects symbolize "muted rebellion" precisely because even as they confirm heteronormative discourse, they simultaneously critique it by calling out its destructive power to erase, disavow, and destroy.

Though the signifier "queer" is often associated with sexuality, it is important to note that in the LGBTQ community, "queer" as a signifier holds a clear distinction from "gay," which denotes desire for the same sex. As Nico Lang explains in his article, "Disney's Long, Complicated History with Queer Characters," queer identity "means to stand in for the Other, whether that's in terms of your sexual orientation or a performance of gender outside the norm" (3). For my purposes, the term "queer" will encompass its initial denotation concerning individuals who display traits of "strangeness, oddity, or eccentricity" (OED.s.v. queerness, a.1) as many of Disney's narrative conflicts stem from a character's queerness as a threat to the "social norms" symbolized by the film. In this broad sense, then, I think it is true that every Disney film contains "queer" elements if only because the cartoon fantasy itself serves as entertainment through which the audience can identify with the possibility that they too might reject social authority, and its normalization of traditional values, if only in cartoon form.

Disney's ostensible resistance to "queerness," then, does not symbolize a fear of so-called sexual "abnormality" so much as it represents Disney fantasy's inability to control symbolic signification and the inevitable return of the repressed. One way in which Disney attempts to undermine this subversion is through the dichotomy of representation between its heroes and villains. Disney's princesses, often hailed as the "good women" of their narratives, are infamous for their large eyes, accentuated beauty, and unrealistically tiny waists. More importantly, they uphold traditional female behaviors of kindness, submission, and a desire for marriage, domestic 
life, and family. Though not as heavily scrutinized, their male love interests are also overtly sexualized by their strength, handsome features, unmatched bravery, and an unheeded desire to save beautiful damsels. Even in animal form, Disney's royalty exhibits a hyper-heterosexual presence like that of their human counterparts. Both Bambi and Lion King, for example, begin and end their narratives with nature eagerly awaiting the birth of its future rulers. Bambi and Faline, King Mufasa and Sarabi, and eventually, even Simba and Nala are all presented as happily married couples, introducing their offspring to their kingdoms as they continue the "circle of life" that heterosexual reproduction promises. Whether in human or animal form, Disney's royalty offers a traditional heterosexual view of the world, creating a stark contrast to the film's queer-coded villains (Putnam 151).

From The Little Mermaid's Ursula to Pocahontas' Governor Radcliffe, Disney villains often "display transgendered attributes — depicted as either strangely-de-feminized women with strong masculine qualities or effeminate men, complete with stereotypical limp-wristed affectation and a touch of eyeliner" (Putnam 147-8). Even Mufasa's treacherous brother, Scar "makes up for his lack of strength with catty remarks and invidious plotting... [using] his body and his tone, much like Ursula did, to carefully craft his transgenderism" as he plots to usurp the throne (Griffin 156). The representation of transgenderism is at once a recognition and a disavowal of its subversion within heterosexual society. Literary critics such as Amanda Putnam, author of "Mean Ladies: Transgendered Villains in Disney Films," argue that presenting only villains in this manner can have adverse effects on Disney's younger audiences: "Dramatic and daring, the villains often outperform their heterosexual rivals, setting up a transparent comparison between 'normative' and 'deviant' gendered behaviors, but also connecting the villains' transgenderism with sarcasm, selfishness, cruelty, greed, and brutality" (Putnam 151). The effect of such negative representation, 
continues fellow critic Adam Key, produces "a disjointed misinformation telling young children that difference is not ok—in fact—-those who are transgendered are evil and to be avoided at all costs" (Key 276).

Disney's adaptation of Peter Pan (1953) encompasses this message through its apparent disavowal of the text's history of "gender-bending"-as its stage version traditionally places a woman in the title role- through Peter's masculine representation, the likes of which many critics have deemed as the "most masculine version of the character" (Griffin 41). Like its predecessors, Peter Pan attempts to teach the roles of masculinity and femininity in a secluded society—albeit this one, formed by children —in which heteronormative behaviors reign supreme, and are subsequently, the natural default. The illusion of heterosexuality as the "dominant" ideology for sexual identification, suggests that those who are queer are "deviant" or "abnormal." But as Judith Butler argues in her essay "Imitation and Gender Insubordination," such polarized binaries are just as unnatural as the concept of gender itself. Butler insists that gender roles are not an instinctual set of behaviors - as Peter Pan seems to suggest - but a performance of learned cultural behaviors. She argues that all identity is crafted through the repetition of performance and that breaks in these performances can disrupt one's sense of identity. Moreover, Butler insists that individuals remain somehow unconsciously aware of the instability of their sexual identity and so act -and are encouraged to act -compulsively to confirm their genders and their heterosexuality ("Imitation" 956-7). For Butler, the child does not develop a sexual identity until puberty, but she suggests that constant exposure to representations of heteronormative behavior informs the basic grammar of the child's understanding of sexual and gender identities long before puberty. In this way, adults pass on learned behaviors through performance to children. 
And yet, in Peter Pan, the main adult figure is not an embodiment of traditional heteronormative behaviors, as such parental units are the very beings that prompt the children's trip to Neverland in the first place. Instead, viewers face a disruptive signifier in the form of the film's villain, Captain Hook, a "campily" dressed pirate who is in constant pursuit of Peter Pan, often aided by his first mate, Mr. Smee. Griffin comments on the dandyism of Hook's appearance and his crew, aligning their mannerisms with those commonly performed by drag queens, "Hook speaks and moves floridly, as if every action was high melodrama. He also dresses the part of a dandy...the pirates under Hook's command are not above singing about the pleasures of being a pirate...[wiggling] their hips in precision like chorus girls" (Griffin 76).

Keeping with Disney's history of renouncing potential queer characters, one can argue that Hook serves as a model of what Peter and his band of Lost Boys should resist. After all, the pirates in the film are the bad guys. Or at least, in the eyes of children who have grown up in the sphere of the social order. However, it is precisely Hook's status as the film's villain that subverts the very nature of it. In other words, to recognize Hook - and those who defy the expectations of gender - as a villain in Disney fantasy is a direct critique of the systems of polarized opposition that make him a villain by emphasizing what he does as a villain. The theatrical nature of Disney villains like Hook emphasizes their actions, mannerisms, and behaviors. Thus, it opens the possibility for analyzing the construction of gender as a repetition of learned behaviors rather than a reactionary set of biological functions. Gender then is not a natural occurrence—as previously insisted by Bambi's forest— but an unnatural system of signifiers that we continue to reenact in a seemingly endless reproduction cycle.

Disney's complicated history with the LGBTQ community reached a pragmatic shift after the Motion Picture Association of America's (MPAA) rating system changed the future of Disney's 
discourse. Adolescents and young adults, the largest percentile of the medium's consumers, were reluctant to attend films with G ratings. Releasing its first PG film, Black Hole (1979), in response to this trend, Disney faced immediate backlash for its violation of promising only to produce Grated films. To appease its family-oriented audience while maintaining a sufficient profit, Disney began producing more mature content under a new name, Touchstone Pictures, acquiring both Miramax Films and the ABC television network in the process (Key 278). Known for its "familyfriendly values," the studio was treading into troubled waters, as some viewers were hesitant to embrace Disney's new “progressively-inclusive” narratives: "The studio is embracing narratives that explore gender and feminism, queer identity, race, and minorities cultures and their mythologies, arguably as a genuine effort towards championing equity. Or, more, cynically, as a commercial response to the current culture of "wokeness" (Law 15).

Internal affairs at the studio took a sharp turn in 1994 as Frank Wells died early in the year with Jeffrey Katzenberg exiting soon after, leaving Michael Eisner to reign over the Disney Corporation. While Disney continued to receive harsh criticism from its aggravated audiences, many feared that Katzenberg's departure signaled an end to the studio's policies surrounding gay and lesbian employees. "Katzenberg held a firm commitment to lesbian/ gay issues," writes Griffin. "Some employees worried that his departure would end the more open and accepting atmosphere at the studio and that the company would backtrack its increasingly overt ties to lesbian/ gay culture and consumers" (215). However, instead of looking back to the "Uncle-Walt" era, Eisner instead turned the studio's gaze toward the very people it had previously parodied, people of color and the gay community.

The release of The Lion King (1994) attracted controversy as members of religious organizations, such as the American Family Association (AFA) and the Southern Baptist 
Convention, began boycotting the Disney organization and its subsidiaries. Among the AFA's complaints was the "objectionable" representation of sex, violence, and graphic language that were coloring the studio's more mature film narratives. In addition to these content issues, many conservative Christian viewers attested against Disney's alleged promotion of homosexuality. Following his announcement that the company would be extending same-sex partner benefits to its employees, the AFA claimed that under CEO Michael Eisner, Disney had become "one of the leading promoters of the homosexual lifestyle, as well as the homosexual political and social agenda in America today." Their leader, Rev. Donald Wildman, adamantly condemned the studio's "insidious homosexual agenda" and labeled [Timon and Pumba] as "the first homosexual Disney characters ever to come to the screen" (Griffin 215, Law 18, Sweeny 130).

Rumors of subliminal messages found in videotapes of Disney's recent animated releases began circulating. Some saw a turret on the undersea castle sketched on The Little Mermaid video box as an erect penis. Others claimed they could see a naked woman's outline on the promotional poster for The Lion King and the word "sex" spelled out in a star constellation during a scene in the film. Lesser-known films, such as The Rescuers Down Under, also came under fire as viewers claimed one scene included a real-life picture of a woman bearing her naked chest out a window (Key 279, Griffin 219). As Sean Griffin notes, these subliminal messages pointed out by protestors are interesting because they strictly focus on the presence of sex - not sexual orientation. The fact that protestors could consciously differentiate between sex and sexuality as separate notions suggests that it is not the representation of sexuality they fear, but the act itself. "What protestors seem to not acknowledge — and probably do not want to acknowledge — are those readings of Disney that blur the boundaries of sexual identities. While going out of their way to convince people that 'sex' has been secretly airbrushed in the night sky of The Lion King, there is no 
awareness that Timon and Pumba [can] be read as a gay couple" (221). By the mid-1990s, a battle for meaning over Disney increasingly ceased to exist. Though one group was pleased by the studio's developments, the other horrified, LGBTQ members and Christian fundamentalists both agreed that "something queer was going on" (Griffin 219).

In its most ambitious attempt to push the boundaries of queer representation, Disney released Mulan (1998), the legend of a young woman that goes to war disguised as a Chinese soldier. As the studio's first East Asian princess and a queer icon, Mulan signaled a new era of diversity within its films. Still, critics such as Cole Reilly questioned whether her narrative was indeed the evolutionary shift the studio claimed it had achieved, "Mulan...must not only fight to honor her father and her family, but she must go to war to save her people. These are not the kinds of challenges any of [her] princess predecessors were expected to face. She achieves much, yet something about [her] story falls short of feeling like [her] own" (55). Indeed, Mulan breaks away from her predecessors' overbearing femininity, but her inability to enact agency except through her performance as a male discolors the feminist vision Disney appears to present. Furthermore, the film attempts to overshadow the transphobic criticism of Disney's past by embracing the crossdressing figure as its heroine yet appropriates her cultural disruption as parody, thus subverting the very possibilities it creates.

The cross-dressed woman historically transgresses the categories of gender through her performance of the opposite sex, thus exposing the instability of its social construction and the cultural codes of masculinity and femininity. "Her illusion of maleness acknowledges its performativity, allowing the woman in disguise to rewrite her role and narrative, exposing the correlation between social 'reality' and 'natural' fact-thus disrupting social norms" (Kornfield 221). The implications of this disruption, though brief in cross-dressing narratives, continues to 
complicate the binary expectations for gender well after the cross-dresser has returned home to her role as woman. Mulan's position as a cross-dresser allows her to overcome the social barriers of womanhood and escape the domesticity of family life to truly be herself — or at least, to embrace a sense of herself that, if exposed, would "break [her] family's heart." Her desire to stop performing the "part" of a "perfect daughter" presents the duplicity of gendered identity within her character: the outer representation of traditional femininity stemming from her biological sex and the inner desire for agency promised by masculinity. Her inability to conform to either of these gendered categories causes a disruption in her sense of identity as she questions which role she must play to be accepted as herself. Overall, the film's failure to provide an ambiguously gendered hero-figure brings to light the interdependence of the very systems of gender and role-playing it seeks to deconstruct.

To properly analyze the cultural transgression of Mulan's performance as a man, it is crucial first to discuss how gender functions as a system of power in society. Understanding how this power structure operates through the binary relationship between masculine and feminine expectations exposes the arbitrary nature of gender and its subsequent socioeconomic construction. According to Lacan, "sexual difference is not a question of biology but of signification; masculinity and femininity are not anatomically given but are subject positions defined to their relationship to the phallus as signifier" (Žižek 63). The phallus—related, but not equivalent in Lacanian terms to the penis—signifies the sense of lack that stems from the child's desire for an unobtainable imaginary object (the objet petit $a$ ) that will always remain beyond reach, as desire can never be satisfied. During the "mirror stage," the fundamental bond between mother and child is broken once the child misrecognizes itself as an individual in the mirror. This prompts the child to embark on an endless search for the fulfillment of desire through the process 
of signification. The phallus thus represents this initial moment of division in the subject and its reenactments as the child grows and matures.

In this sense, the phallus signifies impotence, or lack for both sexes, as boys and girls are both symbolically castrated by the signifier. Castration, for Lacan, requires both sexes to experience the fundamental loss of acknowledging the impossibility of completely fulfilling their desire. The subject's representation of this fundamental loss which the phallus signifies demonstrates a difference between male and female castration. In this model of identification, boys must "pretend" to be the phallus while girls must "be" the phallus. For boys, the phallus symbolizes the eternal return of the Oedipal complex. The Oedipal complex occurs when boys recognize the mother's desire for the father-as-phallus and the father's law against incest bars boys from desiring the mother. Instead, boys must transfer their Oedipal desire for the mother to a new other as dictated by the Symbolic order. For Freud, the Oedipal complex assumes heterosexual desire and is a phallocentric phenomenon which serves to help reproduce cisnormative patriarchal codes and social practices. For Lacan, the phallus is unobtainable because it is not sexual by nature, but rather, it signifies desire for wholeness, the Real, or some sense of control and agency of the sort imagined in the mirror stage. According to Lacan, boys must "pretend" to have the phallus, while girls, on the other hand, must give up an essential part of themselves to "be" the phallus through Lacan's notion of the masquerade.

Drawing from Joan Riviere's “Womanliness as Masquerade," Lacan argues that women hide their true selves behind a masquerade of femininity to appease the anxiety of men. However, since femininity functions as a two-fold representation - that of society's expectations for women while simultaneously, representing women as signifier-it suggests that this masquerade is the construction of a false identity, rather than women's natural identity. In short, 
for women to "be" the desired other -to become the object-cause of the man's desire—and receive the love of men, they must hide away their archaic desire behind a symbolic mask of femininity. This can be traumatic. According to Lacan, for girls to be "a girl", they must identify with the desire to "be" the phallus and all that ensues. As "the phallus," this does not mean that girls are supposed to be masculine so much as it signifies that for girls to be girls, they must be the object-cause of male desire (in a heteronormative ideological context). For boys who must pretend to "have" the phallus (despite their castrated status), masculinities of toxic overcompensation result. However, this can also be traumatic as adhering to such hypermasculinitywhich, in itself, is an arbitrary semiotic code — can similarly restrict the individual to the girl's masquerade. In either case, boys and girls require the confirmation of their gender roles and the proper etiquette for performance. At the very least, to consciously affirm gender expectations to the boy or girl and, at most, to unconsciously cement their placement in the social order through their repetition of its ideological practices for men and women.

Lacan argues that men require women to confirm their autonomy through their lack of having the same parts - the penis (the physical symbol of the phallus) —and it is through this difference which ideology informs patriarchy as a man's sense of power and self-recognition as a masculine subject. Butler further emphasizes Lacan's argument regarding the power structure between men and women through women's signification of the phallus: "For women, 'to be' the phallus means, then to reflect the power of the phallus, to signify that power, to 'embody' the phallus, to supply the site which it penetrates, and to signify the phallus through 'being' its Other, its absence, its lack, the dialectical confirmation of its identity" (Gender Trouble, 59-60). Simply put, gender identity requires constant, compulsive repetition to maintain its fabricated existence. The imitation of masculine and feminine behaviors presents an illusion of consistency. 
Since gender is not biologically or psychologically natural, it exists as the effect of complexities that occur with identity formation, not its cause.

The female subject serves as a reflection which confirms and upholds the male subject's superiority through his physical possession of the phallus - thereby constructing a fantasy of authoritative power. In this scenario, the female subject becomes symbolically subservient to the male subject by lacking a physical phallus. And yet, the female subject's symbolic representation as phallus inaugurates a sense of agency for without her performance as Other through her masquerade as woman, this power relationship between man and woman would not unfold. Without the feminine subject to serve as a "derivative" to the "origin" of masculine identity, argues Butler, the whole system of gender construction would collapse, thereby placing the true power of social construction in the hands of the very women it oppresses, rather than the men who benefit from its "existence." However, since women can only achieve agency in this model by fabricating men's superiority through their lack of phallus, the system of gender identification continues in a supposedly unbreakable repetitive cycle.

The division between male and female expectations is emphasized visually during the opening sequence of Mulan as scenes of battle between the Chinese and Hun armies are juxtaposed to Mulan's transformation into a "lady" as she prepares to meet the Matchmaker. As Gwendolyn Limbach explains, "Becoming a man is an active process, requiring some physical or sexual prowess on the part of the subject. Becoming a woman, in contrast, is a passive process, to be enacted upon a silent object" (119). In other words, to "be a man" requires the subject to physically prove themselves, while "being a woman" requires the subject to physically improve themselves. Feminine expectations are quite direct and superficial in the film, emphasizing beauty and grace rather than an inner sense of subsistence and individuality. The women of 
Mulan paint over their faces with makeup, "masking" their individuality while transforming into the obedient "dolls" culture requires them to be. Lacan states that women walk around in a masquerade in which they shield their true desires with a "mask" of femininity crafted by reflecting cultural codes. Only by adhering to this masquerade of womanhood, argues Lacan, can the female subject earn the love of men.

Yet women are continually shamed for being the "weaker" sex throughout the film, to the extent that even Li Shang, Captain of the Chinese Army, questions if his soldiers are actually "girls" as a derogatory statement, "Did they send me daughters, when I asked for sons?" Unlike the expectations for women, the rules of manhood are not as straightforward. During the training camp montage, Li Shang attempts to "make a man" out of his soldiers by training them for battle against the Hun army. The song "I'll Make a Man Out of You" shrouds the expectations for manhood in simile and mystery, aligning its attributes with nature, "You must be swift as a raging river, with all the strength of a great typhoon" suggesting that masculinity is the natural default. The juxtaposition between war and nature conflates the notion of masculinity with that of strength and brutality, reaffirming the film's message that manhood, and more importantly "honor," is earned through the glory of battle. The only heroic role open to females is through forming a respectable union, as "marriageability" for women equates family honor in the same manner as a male's bravery in battle. This binary between contemporary male heroism and traditional female convention exposes the instability of their construction and will continue to be exposed and challenged throughout the film.

The film opens with Mulan preparing to meet the Matchmaker, a strict, older woman who tests if the young girls in the village have the necessary qualities to be deemed marriageable. Mulan is obviously uncomfortable as she is pushed through stores, stuffed into dresses, and painted into a 
"bride" by the other women in the village. Fully dressed in their bridal attire, Mulan and the other girls walk in a single-file line to the Matchmakers-their physical features covered by makeup applied in the traditional style of the geisha, making them look eerily similar to one another. While the other girls point their parasols towards the ground in front of them, Mulan holds her parasol over her left shoulder like a soldier would his battle staff, quickly adjusting it to the same feminine position as the others once realizing her mistake. Awkward, clumsy, and outspoken, Mulan does not fit the traditional role of a Disney heroine. She demonstrates great wit and courage: winning a checkers match between two older gentlemen and retrieving a stolen doll for a little girl bullied by her brothers. These behavioral distinctions align Mulan with the Chinese soldiers who will eventually become her comrades in battle, demonstrating that while she may dress like the women of her village, she does not act like them. Mulan's inability to adhere to the script of womanhood as taught by her elders brings together Lacan's theories of the masquerade and the phallus with Butler's theory of gender performance, proving that womanhood is an unnatural performance of gender expectations, rather than a repetition of biological behaviors.

Mulan prepares for her test by writing the answers on her wrist with black ink, which smudges onto the Matchmaker's hand. As the Matchmaker corrects Mulan's performance, she unconsciously gives herself a beard with her ink-stained hand, revealing her character's masculine attributes. This action foreshadows the transgenderism that will weave its way throughout the narrative. It also aligns the Matchmaker's appearance with that of a man, suggesting that she serves as a spokesperson for the village's available men. She knows what they desire in a woman and will find girls who will successfully fulfill these expectations. Mulan fails her test, thereby dishonoring her family by not adequately performing her gender role. Mulan's inability to properly perform the expectations of her gender exposes her inner masculinity which the Matchmaker appears to 
recognize as she states, "You may look like a bride, but you will never bring your family honor!" By symbolically failing to uphold her masquerade as a woman, Mulan's heroine status is jeopardized until she can learn to "play the part" the film and more importantly, society expects of her.

Realizing that "womanhood" does not reflect who she really is, Mulan stares into a pond with her feminine masquerade quite literally looking back at her wonders, "When will my reflection show who I am inside?" She then kneels in front of the ancestral shrine, wiping the left side of her face free of her bridal makeup. In this instance, we see two halves of Mulan's faceher natural side that is aligned with her more masculine attributes, and the makeup covered half assigned to her feminine side and the expectations of her gender. From here, the narrative plays with motifs of mirroring and reflection as Mulan attempts to reconcile the outer fantasy she must perform with the inner turmoil of her repressed identity.

According to Lacan, the pivotal moment in a child's development is when they begin to craft a sense of self-the "I"- through their misrecognition of themselves in a mirror. It is through the imaginary opposition between what "I am" and what "I am not" which the mirror reflection offers the child that they use to construct their identity. Knowing that she cannot successfully "play" the "part" of a woman compels Mulan to forge her own heroic role by transforming herself into the only other heroic role available, that of a Chinese soldier. She replaces the draft warrant with the flower comb from her bridal outfit, cuts her hair with a sword, and dawns her father's armor. Mulan even mirrors her father's previously demonstrated battle movement with his sword, holding it in front of her face so the blade divides it in two. Mulan cannot "be" the phallus in the traditional sense of the gender system as she is unable to properly fulfill the feminine expectations of her culture. Since marriage is the only heroic role her society 
offers, Mulan crafts a new agentic narrative for herself through her masquerade as man, thus reentering the semiotic relationship of the phallus as a physical representation of maleness, rather than its reflection.

However, because Mulan physically lacks the anatomical phallus (the penis) she cannot truly be a masculine figure, nor have the social power her masquerade as a man briefly offers. In this vein, Mulan's performance as a man functions in the same manner as her feminine masquerade at the film's beginning. But even this is a half-hearted performance of her inner self, as Mulan clearly states that she has no desire to actually be a man, showing great disgust towards the other soldiers' gross behavior as she walks through the training camp. "Just because I look like a man, doesn't mean I have to smell like one." Furthermore, though Mulan participates when the soldiers sing "A Girl Worth Fighting For," a vocal declaration of their longing for a wife, she does not give any indication that she desires a partner of the same sex. Later in the film, however, Mulan admits that "her decision to go to war on behalf of her father arises not so much out of daughterly concern as her own need to form an identity, so that when she 'looked in the mirror [she] would see someone worthwhile" (Bronklebank 275). Her performance as a man then, is not out of an inner desire to be the opposite sex, but a desire to break free from the social restrictions caused by gender expectations and find her place in society.

Mulan recreates her identity as a soldier named Ping. Upon entering the training camp, her performance of male behavior is heavily exaggerated to the point of being comedic, as even her horse falls over in laughter. Mushu coaches her on how to properly interact with the other soldiers and pass as a man, revealing the performative nature of gender: "shoulders back, chest high, feet apart, and strut!" Mulan's transformation into a man thus reveals the unnatural "reality" which gender constructs through its social rituals of confirmation as she manipulates cultural codes 
through her performance of maleness. For Butler, all gender and sexuality are performative, as identity is constructed through the imitation of cultural expectations regarding masculinity and femininity. She argues that drag performance is especially critical of this notion as it demonstrates that gender can be acted and "worn' and insists that because of this, one's physical sex and gender are separate identities (Gender Trouble, 188). In other words, someone can feel more "like a man" or "like a woman" regardless of their biological sex, suggesting that these are not natural but assumed identities. Since Mulan is a transgendered-coded figure who lacks the physical phallus, and has expressed no desire to obtain it, this transfers the symbolic nature of the phallus, and its signification, from the penis to the film's metaphorical one, the sword.

For Mulan's disguise as soldier to be successful, she must learn how to "pretend" to have the phallus to wield it. The phallus is symbolized in the film by the sword, signifying male power and authority. But before Mulan can wield the sword, she must complete Li Shang's task: fetch the arrow from the top of the pole while carrying two large weights attached to a set of straps—one representing discipline, the other, strength. Where the other men rely on their natural grip to climb up the pole, Mulan realizes that the two straps adjoined to the weights can be tied together to create a band around the pole, allowing the climber to safely inch their way up. Before this task, Mulan had not done anything in terms of agentic performance. Initially failing to keep up with her training, Shang had dismissed Mulan/ Ping, telling them to go home as they clearly did not have the physical ability to be a man. But Mulan disobeys this order, pushing herself to prove that while her maleness is indeed a performance, she too can be a soldier. As Limbach explains, "[the] answer to Shang's question of how he could make a man out of Ping, Mulan demonstrates that he cannot; as the cross-dressed figure it is up to Mulan to make herself a man, to move from passive object to active subject" (120). Dawning her masculine disguise inaugurated her journey but its theatrical 
nature as a form of dress harkens back to Mulan's subservient position as a woman. For Mulan to fully enter the realm of manhood, she must transform from the passive subject into the role of the agentic subject. Only then, the film suggests, will she be able to climb the daunting pole, phallic in its nature, and become the narrative's hero. Mulan proves herself to the other warriors by retrieving the arrow, earning the respect of her fellow soldiers and Captain Shang. With her masculinity secure, Mulan can now venture forward as a "man."

The climax of the film takes place in the snowy mountains. Reaching a village that has been destroyed by the Huns, Li Shang discovers that his father has died in the attack. As the film's leading man, Shang represents the ideal vision of masculinity: he is brave, handsome, cunning, and willing to do whatever is necessary to protect China and prove himself as a leader. He and Mulan/ Ping share a close bond, suggesting a romantic relationship between the two even though they are both "male." Queer undertones aside, Shang serves as a model of masculinity which Mulan hopes to emulate through her performance as Ping. However, the loss of his father demonstrates a new element of manhood which Mulan must overcome, emotional loss. As Charlotte Huck explains in her introduction to Beauty, Brains, and Brawn: The Construction of Gender in Children's Literature, "Boys may show fear if they overcome it with bravery, but they seldom are allowed to cry or show love. Frequently, destroying that which the boy loves has been portrayed as a rite of passage to manhood" (8). Li Shang does not cry over his father's death. Instead, he quietly marks his father's grave by penetrating his sword into the ground, leaving his father's General helmet on top, before turning away to track down the Huns. Shang demonstrates his manhood in this scene by adhering to the masculine code of honor, in this case, that there is no room for emotions in battle. Pushing his grief aside, Li Shang moves forward with the attack, symbolizing his shift into his father's former role as General of the Chinese Army. 
In the context of Lacan's phallus theory, the death of Shang's father functions as a reenactment of the initial fundamental loss a child experiences when they enter the world of signification. Like the men before him, Li Shang demonstrates that manhood is a learned process passed down from father to son. Though a man may perform his expectations, he does not fully enter the realm of manhood until he loses his father—or at least, something he dearly loves. Li Shang loses his father to the war, a fate which Mulan protects her father from through her cross-dressing performance. She does not experience the loss of a parent in the film — a rarity for heroes in Disney discourse. Rather, the potential threat of losing her father propels Mulan to act and perform the role of manhood. But it is not enough to almost lose what one loves into order to truly be a man; loss must occur for the subject to enter the imaginary realm signified by the phallus. Since Mulan has already saved her father, there is only one other possibility for such loss, Li Shang—her film appointed love interest.

After Mushu accidently fires off a canon from the cart Mulan is leading, the Huns discover the traveling troop of soldiers and attack. Quickly realizing they are outnumbered, Li Shang orders his men to stand and fight, "Prepare to fight! If we die, we die with honor." With one cannon left, the soldiers stand ready for what appears to be death. Drawing her sword, Mulan spies a nearby mountain that hangs precariously over the Huns army. Grabbing the final cannon, Mulan rushes across the valley, the rest of the army hanging back in shock as the camera pans out to show one soldier running toward the entire Hun army. The cannon lights at the last second, destroying the tip of the mountain and causing a massive avalanche that takes out the Huns. With the enemy defeated, Mulan/ Ping is hailed as "the bravest of us all!" and deemed a hero. Just as Li Shang expresses his gratitude and trust in Ping, Mulan faints, revealing a cut across her chest from Shan$\mathrm{Yu}$ and subsequently, that she is a woman. 
Once Mulan's biological sex is revealed, the former respect and trust of her fellow soldiers is replaced with disgust and anger. Now exposed as a woman, Mulan is a "treacherous snake" and her former bravery is seemingly forgotten. Here the transgressive nature of drag is fully put on display as the soldiers realize that their "King of the Mountain" is a Queen, thus subverting the traditional notions of masculinity and femininity they have always lived. Butler explains the hostility Mulan faces as a transgendered-figure, stating that in public "the act [of drag] becomes dangerous...precisely because there are no theatrical conventions to delimit the purely imaginary character of the act...there is no presumption that the act is distinct from reality; the disquieting effect of the act is that there are no conventions that facilitate making this separation" ("Performative", 907). Mulan's use of drag demonstrates the performative nature of gender, exposing it and its construction systems as arbitrary and unnatural. To have a woman, the symbol of weakness and submission in their society, defeat their most powerful enemy is nothing short of dishonor, disgracing both the soldiers' manhood and the integrity of their army. By their society's law, Shang should execute Mulan for what she has done. But instead, he shows mercy and abandons her in the mountains, suggesting that perhaps he does hold romantic feelings for her after all.

Though Mulan had initially worn her masquerade as a male to save her father from the draft, her experience as a soldier makes her realize that she did it to find her role in society. The fact that Mulan uses her disguise of manhood to find her true place, rather than her true sex or self, suggests that she is not merely a transgendered figure, but gender-fluid. As Michelle Law states, "Mulan trades one mask for another, the success she experiences with the male disguise only emphasizes her previous failure with the female one" (19). This presents a complex issue. On the one hand, Mulan has already demonstrated her inability to perform the expectations of a woman. 
On the other, her biological sex prevents her from fully becoming a man. Unable to conform to either gender category, Mulan remains barred from society until she can find a role that suits her malleability. Sitting in the snow, Mulan is ready to return home in dishonor-until she sees the Huns emerge out of the snow. Realizing that Li Shang, and all of China, is in danger, Mulan is once again challenged to transform into an agentic subject and "be a man." However, this time when Mulan does so, it is not out of a necessity to uphold a masquerade, but for herself. The emotional loss of Shang's trust-and his potential demise at the hands of Shan-Yu — propels Mulan to create a new role as an agentic subject and find her identity. Mulan cannot "be" the phallus in the traditional sense of womanhood, and now that she is exposed for her true gender, she can no longer "pretend" to have it. In this way, the film casts off Mulan's transgenderismand in essence, her former masquerades - and allows her to be the heroine that carries its name.

Now dressed as a woman, Mulan and her comrades attempt to infiltrate the palace and rescue the Emperor from the invading Huns, mirroring Mulan's transformation and performance at the beginning of the film. To get past the guards, soldiers Ling, Chien-po, and Yao disguise themselves as palace concubines, using the same traditional style of makeup and kimonos which Mulan had worn to meet the Matchmaker. Here the film demonstrates that genderfluidity works both ways: just as Mulan could be a man, here the film suggests that it is equally possible for a man to be a woman. While agency is still heavily signified by masculine behavior in these scenes, the fact that the soldiers fight dressed as women in the most crucial minutes of the film suggests that victory does not occur strictly because of one gender. Rather, it requires both to be successful. It is during these fight scenes at the palace which we see Mulan reconcile the two halves of her identity - the warrior and the woman — to become the heroine the film needs. 
Standing outside the palace, the group of warriors use the sashes from their kimonos in a manner similar to the weight training exercise back at the army camp to scale the pillars of the palace as "Be a man" chants in the background. Shang joins the crew, remaining in his battle armor but using his cape in place of a sash. Where Shang had led their group on the battlefield, he steps back and allows Mulan to take the lead, suggesting that it is femininity, not masculinity, that will save the day. On the palace observatory deck, Li Shang is knocked to the ground by Shan-Yu, the latter preparing a death blows and yells, "You took away my victory!" Mulan quickly steps in, grabbing Shang's sword and pulling back her hair, "No! I did." He gasps, "The soldier from the mountains!" before turning his attack towards Mulan. Perhaps what is most interesting about this scene is that the Hun leader does not comment on the revelation that Mulan is a woman. Rather, he sees her an opponent, and more importantly, a powerful enemy who has thwarted his plans. Considering that Shan-Yu is the film's villain, his recognition of Mulan as an equal refers to the history of "muted rebellion" demonstrated by Disney’s transgendered characters. While Shan-Yu continues to play his role as the villain, this moment aligns him with the cultural transgression of Mulan's transgenderism, suggesting that while the narrative may disavow their opposition to its traditional values, it will still allow the disruption of their presence - the effects of which will echo long after Shan-Yu is defeated.

Mulan and Shan-Yu battle on top of the palace roof as a city of spectators watch in awe and fear. On the roof top, Shan-Yu swings his sword at Mulan, the symbol of the phallus, while she defends herself with a paper fan, the symbol of femininity. He strikes her, impaling the fan with a deadly smirk. Mulan quickly closes and twists the fan, disarming Shan-Yu and propelling the sword into her hands. "The conferral of her enemy's sword effectively bestows upon Mulan an officially condoned phallus, marking her instead as male" (Limbach 125). With her enemy's 
sword in her hands, Mulan is symbolically marked as the narrative's hero, ensuring her victory, and implying that this is the role she was meant to perform.

With Mushu lighting fireworks behind her, Mulan strikes the sword through Shan-Yu's cape — effectively pining him to the roof as a large rocket strikes him dead. With the Huns finally defeated, Mulan stands atop the palace with her sword lowered to her side as China cheers around her. Even after Mulan has proven herself as a warrior by saving the Emperor, there is still resistance to her hero status because she is a woman. Chi-Fu, the Emperor's royal advisor, immediately calls for her arrest, though Li-Shang comes to Mulan's defense, "She is a hero!" "She's a woman," ChiFu responds, "she'll never be worth anything.” The cultural aggression towards women in Mulan's society serves as the barrier she fights throughout the film. Chi-Fu's comments suggest that it does not matter that Mulan has achieved what even China's greatest warriors could not; honor may only come to a woman through marriage. Mulan may have succeeded as a warrior, but she has failed as a woman.

Despite this harsh criticism, the film still attempts to produce a progressive message through its elderly Emperor. As the voice of authority, the Emperor, and his word, is the Law. Serving as the Big Other of society, he enforces its ideologies, punishing those who oppose its rules and praising those who uphold them. The Emperor bows to Mulan, an honor that he would not bestow upon Shan-Yu even under the threat of death. Her fellow soldiers and the spectators surrounding the palace follow his example, suggesting that China recognizes Mulan as their hero. Impressed by her heroism, the Emperor offers Mulan a position on the Royal Council. But she refuses, stating that she wishes to return home instead. Rather than leave her empty-handed, the Emperor sends Mulan home with two gifts: the crest of the Emperor, "So your family will know what you have done for me," and the sword of Shan-Yu, "So the world will know what you have 
done for China." Back at home, Mulan reunites with her father, presenting him with these gifts. However, he casts them aside and embraces his daughter instead, suggesting that he has finally overcome his own prejudices and accepts his daughter for who she is, rather than what their traditions expect her to be. Perhaps if the film had ended here, Mulan would genuinely be regarded as the feminist icon Disney hoped to create. But Mulan's tale does not end with a celebration of her achievements as a woman. Instead, the final scenes return to the very place she had attempted to escape in the first place: the domestic sphere of the home.

Despite all that Mulan has accomplished, the film makes it clear that her journey is not finished as she is still single. Her grandmother says, "Great, she brought home a sword. If you ask me, she should have brought home a man." In true Disney fashion, the film ends by rewarding Mulan with the proper gift for a woman, a husband. In its final moments, the film quickly tries to subvert any queer undertones by setting up Mulan and Shang in a romantic relationship. Now that Mulan is a woman, Shang is suddenly a bumbling mess, unable to form a coherent thought in front of her- a far cry from the stoic warrior he has been throughout the film. Even the Emperor comments on their potential relationship, "You don't meet a girl like that every dynasty." Now back at home, the film suggests that Mulan's experience has allowed her to reconcile the two halves of her identity: the heart of a woman and the strength of a soldier, allowing her to fulfill her culturally appropriate role as Shang's future bride.

The shift from the battlefield setting to that of the homestead grants Mulan an agentic role in their relationship as she has had the domestic training which Shang appears to lack. Just as he had taught her how to be a soldier, she will teach him how to be a husband. By pairing the two most overtly queer characters into a heterosexual relationship based on their biological gender, the film undermines its potentially gay narrative by ending in the Disney traditional, conservative 
trope of marriage in spite of all that has come before. Though Mulan's story ends within a heterosexual ideological matrix, the ideological disruption caused by her transgenderism nevertheless indicated a desire in Disney to represent diversity in their princesses even while appropriating and contorting pseudo-Chinese tradition in the name of expanding their global reach. While more examples of feminist princesses would emerge over the following decades, fans of the LGBTQ community would wait almost twenty years before Disney finally introduced its first lesbian-coded princess, Elsa, in 2013. 


\section{Frozen: Becoming a Queen}

As Disney releases new films yearly, exposure to its animated adaptations has elevated the traditional heteronormative narrative and its expectations for gender and sexuality to a global audience. In spite of what may appear to be an evolution in how Disney media represents gender and sexuality, Disney media's reinforcement of culturally accepted behaviors appears throughout its film history; heroes and villains repeatedly perform the same representations of gender and the underlying expectations for their respective roles. In Frozen (2013), one of Disney Animation Studio's most successful animated films ever, Disney not only upholds the traditional heterosexual models of gender and sexual identity but also reinforces heteronormativity as the superior social narrative, rather than providing the progressively feminist and "homosexually-inclusive" narrative which it teases its modern audience. Much critical and popular discourse read into the Anna and Elsa dyad a latent homosexual thematic. Elsa's repressed sexuality, it could be argued, makes her the classic hysteric, driven mad by her repression. Furthermore, Disney's "bait and switch" narrative in Frozen models preferred norms of sexual and gender identity. Frozen is nostalgic for its cis-gendered antecedents, I would argue; the fantasy narrative baits its target audience with a message of difference and otherness while then favoring the very fairy-tale conventions it undermined in the first act of the story. The Frozen narrative informs its widely-available merchandise, and together Disney reinforces its role as a pedagogical agent of social ideology.

Though well known for its advocation of childhood innocence and nostalgia, the key to Disney's successful pedagogy is far less magical than its colorful mascots would suggest. Rather than use pixie dust or a child's wish, the alluring power of its animated films stems from a psychological phenomenon known as Social cognitive theory. In his essay, "Social Cognitive Theory: An Agentic Perspective," psychologist Arthur Bandura argues that children develop and 
learn socially acceptable behaviors by observing others performing them (15). A child's recognition of behavioral expectations typically occurs during their developmental stages-ages two through five - in which they are heavily dependent on another nurturing figure, their caregiver. Bandura's theory builds on Lacan's notion of the "mirror stage." In the "mirror" both literal and figurative, the child misrecognizes itself and pursues the perfection of this illusion from then on. What the child sees in the mirror are the signifiers that make up the Symbolic Order, the order language, and their environmental culture that lie behind social cognitive theory. The world of the symbolic is everything, and so it necessarily informs the child's development as a subject of ideology as a result of their constant exposure. From there, the child's ego development is constructed by their desire interacting with the symbolic world all around them, and the behavioral expectations that follow. Once the child has successfully internalized the favored performative behaviors, their actions and mannerisms will reflect and adhere to the limitations of "good behavior," as regulated by their caregiver. In this way the child is interpellated by ideology in order to turn the individual child into what Althusser calls "the good subject."

At its basic level, social cognitive theory argues that child development is an advanced form of imitation. Children learn through play; the rules of their imaginative worlds often reflect the values taught to them by their parents during intellectually engaging activities such as reading, playing games, or watching educational television. A child's desire to be "like daddy" or "like mommy" proves that children recognize behavioral patterns and will reenact them in order to make their sense of identity match their idolized model, or what Lacan calls the "ego ideal." According to pedagogical critic, Laura Padilla-Walker, three compelling circumstances need to occur for the child to successfully embody the observed behaviors they desire to imitate: First, the child must notice, recognize, and store the memory of the current behavior in their mind. Second, the child 
must be exposed to an aesthetically pleasing — and preferably, demographically similar — character repeatedly performing these behaviors. Third, the child should be encouraged to imitate the behavior through rewards and punishments; the initiator of the action receives praise for the correct behavior and discipline for the incorrect behavior (2).

Children are more likely to emulate favored habits of behavior if they watch a representation of "ideal feminine beauty" that both resembles and does not resemble them in age, gender, or race performing it. The ideal exists only in fantasy. According to Lacan, the child is driven by desire to assemble an "ideal ego" from the "ego ideals" offered by culture and discourse. Today's young audiences typically find such figures in their morning cartoons in characters such as Dora the Explorer, Steven Universe, and even the helpful pups of Paw Patrol whose acquired knowledge from more experienced individuals teach them the skills they need to overcome the obstacles of the day's episode. While older children can grasp the articulated lessons of these programs, even if they don't fully understand their meanings, younger children are often attracted to the bright colors of the animation, thus keeping them active viewers until they also reach this age of recognition and understanding.

Before children are exposed to media, this transfer of information through performative action occurs through their first experiences with the "big Other" of their social sphere, their primary caregiver. When children are born, their first interactions with a figure outside of their sense of self is the mother or assigned mother-figure whose presence is a source of nurturing guidance and symbolic information. Although children can identify these figures from their earliest cognitive awareness, Lacan argues that the child does not recognize its subjectivity as a real presence until it reaches a pivotal moment in its development called the "mirror stage." At the age of six months, the child can recognize its reflection in a mirror. Once the child fixates its sense of 
physical self-unto this reflection, it then constructs its identity within the context of its surrounding environment through the duplicated reality presented by the physical mirror (Lacan 442). In other words, a child only begins to create its sense of identity or "self" once it can move past this initial misrecognition of itself as a stranger in the mirror and realize that the projected "other" staring back is their reflected image. Lacan insists that the child's misrecognition of its reflection as a subject complicates the transfer of pedagogical agency between itself and its models of social identity as its sense of being can only be achieved through the constant comparison of its "self"the subject they identify as "I"—with "other figures."

The child's sense of identity through binary opposition is crucial to ego-development as it regulates the fabricated superiority of heteronormative behaviors and their performances in social culture. Judith Butler examines this cultural phenomenon in her essay "Imitation and Gender Insubordination" through the construction of gender: "gender is a kind of imitation for which there is no original; in fact, it is a kind of imitation that produces the very notion of the original as an effect and consequence of the imitation itself" ("Imitation", 956). Butler argues that both gender and sexual identity are constructed through the repetition and imitation of cultural expectations regarding masculinity and femininity, even though they are biologically unnatural. Though Butler's primary focus is the construction of these identities, she insists that all identity is crafted through performance and that breaks in these performances can cause a disruption of identity. Moreover, people are subconsciously aware of the instability of identity and compulsively repeat acts to confirm their heterosexuality ("Imitation", 956-7). Since children learn their social behaviors and expectations through the observation of others, these performances of heteronormativity are always in effect as new generations grow and develop, eventually passing on these learned behaviors through performance to their children. 
Although the child does not develop a sexual identity until their pubescent years, Butler suggests that the regulation of heteronormative behaviors constructs the child's sense of proper and improper sexual behaviors quite early in their development. In binary oppositions, the symbolic order represents one side of the binary as the preferable trait, while the other is the "deviant" or inferior. Though the binaries of male/female and masculine/ feminine are the most prominent examples in our own culture, Butler's focus on heterosexuality/ homosexuality provides a distinct pedagogical model of heteronormative behavior in the crafting of children's sexual identity. The traditional binary of sexual identity represented homosexuality as the inferior sexual orientation to heterosexuality. It is common to hear of homosexuals who are physically and verbally violated for their sexual preferences. Though there is no biological evidence supporting the claims that homosexuality is unnatural, children's exposure to the violent acts against homosexuals by social authorities regulates the heteronormative agenda through the same models of reward and punishment outlined in social cognitive theory. If we consider these models of behavior as reinforcements of socially-acceptable identity, then the child's construction of itself as a subject is not just an imitation of language and behaviors, but a regulation of the ideologies performed by the "other" figures of their social spheres. The child's cognitive recognition of its sense of identity as a natural subject through these models of regulation is vital to Disney's social pedagogy as it serves as the foundation for which it can impose its ideologies. The victim is the child-subject who, having embraced the role of "good subject," may struggle against their biological nature for a lifetime.

Disney's films have undergone a "cultural transformation" through the past few years as a new "revolutionary-style" of the Disney princess has slowly emerged to placate feminist critiques of the traditional Disney princess. The new Disney princess as she appears in Frozen is a feminist 
repudiation of her predecessors: Elsa is brave, self-reliant, and even more shockingly, learns that finding 'true love' at first sight is a lie. However, a closer reading reveals that Disney has not embraced a new form of the female protagonist at all. Rather, these new agentic princesses are a cynical and self-aware effort to represent feminist values while at the same time undermining those messages in favor of traditional representations of gender and sexuality.

One of the most successful examples of Disney's "bait and switch" narrative strategy is the Oscar award-winning film, Frozen (2013), inspired by Hans Christian Anderson's fairytale, "The Snow Queen.” The film imagines the origin story for Anderson's "Snow Queen.” She comes from a dysfunctional family — it turns out—and is emotionally abused by her parents; she lives in shame, alienated from herself and a needy little sister. In the end, the little sister, Princess Anna of Arendelle, must find her big sister, Elsa, the Snow Queen, and save their kingdom from eternal winter. Kept within the palace walls all her life, Anna dreams of meeting her 'true love' and to escape the lonely confines of her home. Although her primary objective in the film is to find Elsa and restore the emotional bond they had as children, Anna's desire for 'love at first sight' embodies the traditional feminine values of love and marriage, values that Disney has advocated for years. Elsa, on the other hand, is marked as the social outcast of the film by her special powers. A victim of emotional abuse by her father, the king, Elsa learns to "conceal, don't feel" as a mantra of repression from him. He demands she deny part of herself, and that she should fear her abilities and repress any desire she may have to use them as much as he desires it. This repression of Elsa's powers suggests that the King is following the regulation of social values by punishing Elsa for being abnormal, as her powers do not fit the feminine expectations of a woman, or more importantly, a future Queen. 
Furthermore, the King's decision to separate Elsa from Anna appears to inherently awaken Elsa's desire for Anna as the two sisters use their nostalgic memories from when they played as playmates to cope with the isolation and alienation they live with as adolescents and young adults. The King forbids Elsa to have any social contact other than him. His desire for Elsa becomes apparent as it shapes his daughter's identity to fit his ideal mold of princess femininity. Elsa's relationship with the King symbolizes how social regulation informs her mental and physical transformation into the "good subject" as determined by her father. She regulates her behaviors and represses her desire until she snaps. If we consider Frozen as a model for Disney's social pedagogy, then the film's ideological message performs a "bait and switch" maneuver with the viewer. While its conclusion seems to celebrate the power of "sisterly love," it simultaneously restores via nostalgia the patriarchy of her father's kingdom and its ideals through Elsa's return to the kingdom as its rightful monarch.

The film opens with the initial waking of traumatic desire for Elsa when she and Anna are young girls in Elsa's bedroom. "The sky is awake," which means that Anna has come to play with Elsa — even though it is the middle of the night and Elsa is in bed. While innocent enough, the scene appears to have some sexual undertones as we see Anna intimately climbing on top of Elsa, bouncing on top of her and begging to play. Elsa coyly pushes her sister off the bed saying, "Go play by yourself." To which Anna, persistent in her efforts to connect with her older sister, hops back up on the bed and whispers to Elsa, "Do you wanna build a snowman?" a request for emotional connection which will be repeated continuously throughout the film. It is through their play that Elsa's ice powers are revealed; including the traumatic incident in which she almost kills Anna with an ice blast to the head while trying to catch her. Terrified, young Elsa instinctively 
calls out to her parents for help and comfort. Yet, as we soon discover, it is precisely this natural desire for her parents that causes the conflict of the film.

With Anna in trouble, the King and Queen take her and Elsa to see the trolls, social outsiders who recognize social authority and magic, including Elsa's powers. After saving Anna, Grandpebby, the wise leader of the trolls, warns Elsa that "fear will be your enemy." Wanting to protect his daughters, the King devises a plan to keep them safe: they will lock the castle gates, reduce the staff, and most importantly, keep Elsa out of contact with people and her powers hidden from everyone, including Anna. While it is evident that this plan is entirely in opposition to the troll's advice, it appears to serve two essential purposes for the King if he desires Elsa as an object. First, it allows him to keep Elsa confined to her room with limited contact; he must approve all visitors before entering. Secondly, it separates Elsa and Anna, breaking the intimate bond they had as children.

The King's pursuit for Elsa gets stronger as she, and her repressed powers, develop under his instruction. Elsa's fear of her ice abilities limit her control over them; when she feels scared or threatened, ice forms over her hands and anything she touches. When Elsa's father gives her gloves to help "conceal" these instances, the structure of the scene is eerily similar to a marriage proposal. Elsa stands in front of her father with one hand stretched towards him while he is down on one knee. After slipping the glove over Elsa's hand, the King takes it in both of his, and together, they recite the mantra which Elsa shall live her life by: "Conceal it; don't feel it; don't let it show." This proposal between Elsa and the King becomes a marriage of social expectations as they recite the "vows" which Elsa will follow while wearing the symbolic presence of her father and the laws she must now abide by her gloves. In her teen years, Elsa is shown panicking as her powers are indeed getting stronger. She backs into her bedroom corner, the walls covered in ice-a visual reminiscent 
of ejaculation — as her father moves towards her. The Queen, her mother, remains standing off to the side in silence. As the King comes closer, talking to Elsa in a calming voice, her fear visually increases. She screams, "No! Don't touch me!” Before adding in a softer voice, "Please, I don't want to hurt you." The entire time this is taking place the Queen, her mother remains behind her husband, completely silent. Her only reaction is placing a hand on the King's shoulder, while still keeping her distance as if to remind him of her presence in the room.

As the King of Arendelle, Elsa's father is the symbol of law and authority in their societyhis word decides what is acceptable behavior and what is not. These moments from Elsa's childhood demonstrate how the laws of society shape a child's identity through the regulation of behaviors as the law itself teaches Elsa her social skills and mannerisms. These lessons between the King and his daughter represent the very social customs he wishes to impose upon her: he marries her, forces his heterosexuality on her, and even keeps her mother in view as a model of what he desires her to become. The visual ejaculation in Elsa's bedroom - the ice she stands in suggests that the King has marked her as a social subject through his masculine essence. Elsa belongs to the king and his order, to disobey his lessons of repression will lead to social ruin and ultimately, further isolation. Elsa's immense panic towards her ice powers demonstrates that she is well aware of these consequences, hence why she agrees to wear her gloves and follow the rules which her father has imposed on her.

Between these scenes of Elsa's childhood, Anna is maturing into a young woman, repeatedly knocking on Elsa's door and asking, "Do you wanna build a snowman?" - the last activity she and Elsa had performed together. Each time Anna addresses this request to Elsa, she is rejected. Anna eventually grows tired of Elsa's rejection; she learns to pass Elsa's room without asking, yet still delivers a wanting glance at her closed door. Anna only resumes her efforts after 
their parents are killed in a shipwreck. When the King and Queen pass away, the barring presence of the "Big Other," their father, has vanished; prompting Anna to finally reconnect with Elsa with her initial request, "Do you wanna build a snowman?” Instead of a vocal response, the scene shows a visual parallel between Anna and Elsa as they sit back-to-back against their respective sides of the door. Anna is clothed in mourning attire in the hallway while Elsa appears to be wearing the same gown she wore when her parents departed. Most notably, Elsa's room is covered in ice. She cries in the middle of the ice blast, its shards radiating throughout the room. As this moment suggests, Elsa and Anna have lived lives of repressed desire: they want to be together but cannot be due to their father's beliefs and his ability to enforce them. While Anna can dream and allow her desires to flourish into fantasy, Elsa remains trapped in his essence as the traumatic undertones of his lessons taint her ice powers, and more importantly, the memory of Anna's accident.

Although most of Elsa's internalization is emotional, we see the physical connotations of her father's ideologies on Coronation day as she is now a fully grown woman. Visually, she looks exactly like her Mother: sporting the same hairstyle, presenting the same regal posture, and even has on the same style of dress, but in different colors. As Elsa practices for her coronation, we see her doing so in front of her father's portrait - mirroring his actions while repeating the "vows" she had taken during his "proposal": "Don't let them in, don't let them see. Be the good girl you always have to be. Conceal, don't feel, put on a show. Make one wrong move, and everyone will know." As if to emphasize this point, Elsa then takes off her gloves and attempts to copy her father's portrait by lifting the royal sphere and candlestick, only to watch them become covered in ice as her hands make contact. Concerning visuals, it is no surprise that these symbols of royal power are incredibly phallic. While the sphere is a ball, a metaphorical representation of the testicles, the 
candlestick aligns with the phallic image of the penis - the biological components of her father's sexual desire.

Though Elsa's social development is a crucial component of her character, the film only provides brief moments in which we see Elsa learning to control her powers under her father's instruction. Now, as she is about to assume his place of power, we see the full effect of his teachings: on the outside, Elsa is quiet, poised, and beautiful; just like her mother. However, on the inside, she is emotionally unstable as she not only fears her powers but the very society she has been isolated from, and now has to rule. The real test of Elsa's lessons come after her coronation when Anna, Elsa's repressed desired, is compromised by the handsome prince, Hans.

A direct critique of Disney's trope, 'love at first sight,' Elsa defies the social ideals of the "Big Other"- in this case, Disney — as she blatantly tells Anna, "You can't marry a man you just met." Naturally, this causes a fight between Elsa and Anna. Anna's desire for their nostalgic past and 'true love' is placed in direct contrast to Elsa's repressed desire for her sister. It is here that Elsa fails: she "feels" her emotion, loses control of her powers, and then reveals it for everyone to see. Elsa's desire for Anna causes her to directly oppose her "Big Other," their father, as she breaks the "laws" that he had taught her, thus making her a criminal of the social order.

As Elsa runs away, her secret now exposed, she stops for one woman; a young mother, holding her giggling baby who asks, "Your majesty, are you all right?" For a moment, we see Elsa hesitate to respond. Elsa's mother did not appear to have a true role in her life. She merely served as a model of what the King, her husband, desired Elsa to be: beautiful, silent, obedient, and more importantly, submissive. When Elsa meets this young mother on the street, she instinctively reaches out as if trying to grab onto the one familiar figure of stability she had, her mother. Considering that the Mother is the first "other" we come in contact with, this scene suggests that 
Elsa is trying to recapture that initial sense of comfort. However, as indicated by Elsa's hesitation, we know that such comfort cannot exist except through nostalgia — the very thing which Elsa must resist due to its connection with her traumatic past with Anna. Once Elsa realizes this, she panics and unleashes her powers against the men chasing her; causing the mother to immediately back away with her now screaming baby as Elsa has broken the most important rule of her "Big Other": don't let them know. With her secret out, Elsa has only one means of salvation, escape.

Elsa runs deep into the mountains, spreading her secret across the kingdom in the form of eternal winter while performing her infamous song, "Let It Go." According to the film, "Let It Go" is Elsa's pivotal moment of self-discovery as she finally overcomes her fear of social judgment and embraces her ice powers, transforming into the beautiful Snow Queen. Even the most blatant critics of Disney's female representation, such as Cole Reilly, agree that "tucked away in the mountains a good distance from Arendelle, where she need not fear hurting others, Elsa finally feels safe to explore the seemingly endless possibilities of her magic gifts - to be playful again even, for not since childhood has she been able to see this facet of herself with joy" (59). Visually, Elsa seems spiritually empowered: she takes off her gloves, rebuilds Olaf, the snowman of her childhood with Anna, and even constructs an ice castle of her design, complete with a dazzling chandelier. If we consider this scene regarding Elsa's social development, then this entire sequence can be read as her "mirror stage" as Elsa's misrecognition of herself as a free spirit hides the reality that she is only diving deeper into the fantasy which her father had constructed for her.

Although Elsa runs away from her repressive society, she still subconsciously upholds its values as she verbally reaffirms its expectations through her song's lyrics. Her childhood mantra returns in the opening lyrics, "Don't let them in, don't let them see, be the good girl you always have to be." As Bandura argues, the ego is the primary source of human agency; the ideals that 
shape it are taught in childhood (6). Elsa repeatedly praises her past actions as she advises herself to "turn away and slam the door" and forget all her problems. Elsa finds comfort in isolation; she can do whatever she desires because there is no one to judge her actions. Her empowering "castle" is nothing more than a physical, phallic symbol of the emotional walls from her childhood, allowing Elsa to "shut out" the world like her bedroom door. In this way, Elsa is not embracing her powers. She is just reaffirming the repressive behaviors taught to her during childhood.

Along with her new castle, Elsa symbolizes her "rebirth" by tossing off her crown, the symbol of her authoritative power while stating, "the past is in the past." Her conservative hairstyle and dress transform into a messy braid and highly sexualized, glittery gown that hangs off her shoulders and has a long split running up her leg. To complete the image, she exits onto the balcony with a sexy, swaying strut in high-heeled shoes. Perhaps what is most disturbing about this transformation is the fact that Elsa could not have designed this gown by herself. After all, Elsa has spent her life in isolation with only her conservatively-dressed mother and possibly a few other professionally-dressed female servants as models of femininity. Where then, would she have seen this type of dress? Considering Elsa's lack of contact with the outside world, there is only one person who could have shown her this style of dress, her father. If Elsa is the object of her father's sexual desire, then we can assume she has learned his ideas regarding female sexuality, or at least, his fantasy of it. As Elsa is changing her attire, she states, "That perfect girl is gone." Or is she? Elsa's original style was an imitation of how her mother had dressed when she was still alive. If we consider Elsa's transformation concerning her father's desire, then Elsa is not breaking away from the feminine expectations he had taught her but embodying them.

The most impressive feature of Elsa's castle is the giant chandelier that hangs directly above a snowflake. Here we are presented with two distinct symbols: one of phallic nature, the 
chandelier, which represents the King; and one of individuality, the snowflake, which represents Elsa's desire. The two are parallel to one another; face to face but never touching. The placement of these symbols is reminiscent of Elsa's relationship with her father as his desired object: he can watch over her, be there for her, but they must never touch intimately. This reading of the chandelier also applies when Hans and his men invade the castle. Oddly enough, two of the men look physically similar to both Hans and the deceased King. When they attack the castle, Elsa nearly kills them with her ice powers: opting to penetrate the "Hans" figure in the throat while quite literally pushing the "father" figure out the broken door. She shows no mercy until the real Hans comes forward and pleas, "Don't be the monster they fear you are." When the "Hans" impersonator tries to shoot Elsa with a bow-and-arrow, real Hans redirects the shot upwards, causing it to hit the phallic chandelier above their heads. The chandelier comes crashing down on top of Elsa, shattering it to pieces as it slams against the symbol of her snowflake on the floor. Elsa has spent her life repressing her desire to be herself with Anna, as she had learned to do from her father. Although he is physically gone, his presence is always looming over her head, constantly reminding her of the expectations she must adhere. When Elsa's chandelier breaks in the fight, it symbolizes her defeat at the hands of the patriarchy as the phallic symbol destroys her fantasy in the same manner which her father destroyed her childhood innocence. In this way, the film seems to suggest that Elsa's desire to kill her two assassins are not out of hate for them, but the repressing figures they resemble, Hans and her father. To escape them would mean that Elsa would finally be able to achieve her real desire, Anna.

One of the most critical moments in the film is Anna's "death," as she freezes solid from one of Elsa's ice blasts. Anna spends the majority of the film searching for Elsa and her 'true love,' or at least, someone who can show her what love truly is. Before Anna can fulfill this desire 
through her 'film-appointed-lover,' Kristoff, she sees Hans attempting to assassinate Elsa with his sword. Giving Kristoff a final glance, Anna throws herself between Hans and Elsa as her body freezes solid. Hans' sword shatters against the impact and the repercussions knock him backward, leaving Elsa with Anna's body. While Anna's "death" is the climax of the film's story arc, its true importance is Elsa's reaction to it: she cries. Throughout the entire film, no matter what Elsa has gone through, she has let her powers reveal her feelings through colored ice, her castle changes color based on her emotions, and storms. When Anna "dies" from her actions, Elsa's heart finally "thaws"- the emotional barriers she has built come crashing down, allowing her to honestly feel the emotions she has bottled up for so long.

Once Elsa cries, it appears the film has reached its resolution as Elsa's tears defrost Anna. When Anna runs to Elsa instead of Kristoff, her implied 'true love,' Anna willingly gives up the chance to fulfill her desire in order to save the last connection to her nostalgic past, Elsa. By sacrificing herself for Elsa, the film implies that Anna has fulfilled her desire as she has demonstrated the true definition of love: "putting someone else's needs before yours." Moreover, this emotionally intimate moment between the sisters almost crosses the territory of visual lovers as Elsa and Anna are shown holding each other's hands in their own as they speak:

Elsa: "Anna!"

Anna: "Oh, Elsa."

Elsa: "You sacrificed yourself for me?"

Anna: "I love you."

As if this message was not clear enough, Olaf, the symbol of Elsa and Anna's desire and the film's appointed "love expert," comes forward and directly says, "an act of true love will thaw a frozen heart." With that, Elsa suddenly realizes how to unfreeze Arendelle and save the day, with love. 
When Elsa and Anna embrace, Elsa finally gets her heart's desire, Anna's love. Elsa's internal conflict is finally at peace as she clears away all the ice, the symbol of her fears, from the land and compiles it all into one giant snowflake in the sky, before blasting it into a shower of glitter with a smile. If we consider Elsa and Anna's desire for one another, then the film's resolution is not the classic trope of 'true love's kiss,' but the emotional bond between sisters, that saves them all.

Now with her powers under control, Elsa willingly opens the gates and turns the castle courtyard into an ice-skating rink for the townspeople to enjoy. Even Anna gets in on the fun as Elsa transforms her boots into ice skates, clasping Anna's hands in her own, and pulling her around encouragingly. Once again, the film presents an intimate moment between Elsa and Anna as they ice skate together with Olaf directing them along the way. As the camera pans out, it appears as if the two are waltzing together while Kristoff — assumedly Anna's new boyfriend — watches from a distance; suggesting that their desire for another has been fulfilled and thus, has brought the film to its happily ever after.

However, this is not the final scene. The last frame of the film is an overview of the castle - the symbol of authoritative, phallic power and the "Big Other" - now blue with Elsa's essence. Along with this color change, Elsa's snowflake is now embedded in the middle of the highest tower, giving off a slight twinkle as the camera pans out. Although viewers may be satisfied with the feminist ending the film appears to present, this final image of the castle implies that the resolution of the film is not the power of "sisterly love," but the restoration of the nostalgic patriarchy through Elsa's return.

Everything that Elsa knows about life, from her ideas about self-desire to her fear of society, was taught to her by the "Big Other," her father. It was through the King that Elsa learned to isolate herself from society and keep her desires hidden behind closed doors and concealing 
gloves. It was through her father that Elsa learned how to be the "perfect girl" by watching her father reward her mother with love. In her new sexualized form, Elsa fully embodies her father's ideas about desire as she not only physically resembles the feminine standards of the "Big Other"-in classic Disney style — but also spiritually, as she has obtained the love of Anna, her desired object, by restoring the nostalgic, emotional connection from their childhood. In this way, the film suggests that Elsa has not truly freed herself from the social order. Rather, she has learned to "cover up" the traumatic reminders of her painful past with the same barring essence that had kept her isolated from the world in the first place-her ice powers.

After all, if Elsa had truly conquered her past and taken control of Arendelle, then wouldn't her snowflake sit at the top of the highest tower instead of directly in its center? A closer look at the ice-skating scene between Elsa and Anna shows a direct parallel to the glove scene between Elsa and the King earlier in the film. Elsa covers Anna with her own "weapons" against the icein this case, skates to skim on top of it, rather than gloves to conceal it—-before grabbing Anna's hands in her own. Although they do not exchange "vows" in this scene, Olaf, the symbol of their childhood desire, guides Anna along the way. In this light, the film suggests that Elsa does not overthrow the old order with her return but remolds her image in order to integrate back into society and assume her role as Queen. By taking up her father's ideological cause, the film suggests that Elsa has internalized his lessons as the "correct" way to behave and will follow their example so she may stay with Anna, her desired object, at the castle.

It is incredibly cynical and yet, Frozen ranks as the highest grossing Disney film of all time. As Henry Giroux argues, Disney's control over most of today's media stations allows “animated films to provoke and inform children's imaginations, desires, roles, and dreams while simultaneously regimenting effect and meaning" (Mouse That Roared, 98). The primary reason 
Frozen was so popular when it first premiered was that it appeared to undermine Disney's old conservative values regarding romance, 'love at first sight,' and the fragile nature of women. The "sisterly love" that Elsa and Anna suggestively promote fulfills the desire of modern-day Disney fans across the globe as they are the heroines of the film, rather than the more traditional pairing of Anna and Kristoff. This illusion of feminine power is why the movie is so dangerous. Disney can control the social curve by molding the images of its films just enough to satisfy its viewers while still subconsciously maintaining its ideologies. While Disney may change aspects of its characters to meet society's desires, it is still the one controlling the underlying messages of its films.

As society's "Big Other," Disney uses symbolism and language to "teach" its ideologies to children in the same fashion which a caregiver, such as Elsa's father, demonstrates and teaches their values to a child. While older viewers may criticize Disney for the unrealistic looks of princesses like Elsa, children see them as a beloved character they wish to imitate. On the playground, it is children who belt out the lyrics to "Let It Go," while dressed in their sold-out Elsa and Anna costumes, enjoying the movie and toys they have purchased and played with over and over again. Disney has maintained its social power by marketing to the desires of children, and more significantly, their parents. It is through this misguided pedagogy that Disney can keep a grasping hand on its growing audiences and under this, a direct link to social culture. 


\section{$\underline{\text { Conclusion }}$}

Despite its progress in representation and diversity, Disney continues to follow its conservative tradition of disavowing queer characters: Flower produces a son, Mulan marries Shang, and Elsa becomes Queen. These "queer" characters cause a sense of disruption in their film narratives by portraying gender and or sexual fluidity. However, they eventually succumb to the influence of their respective societies and remold their outer performance to fulfill whatever role the "Big Other" (Disney) crafts for them. Yet even as this repression of their queerness occurs, Disney's "queer" characters still exhibit a sense of resistance through the "muted rebellion" of their hidden desires. Flower eventually mates with a female skunk and produces a son, but he names him Bambi—a female signifier — thus granting his child the same chance for genderfluidity which his childhood friends allowed him. Mulan and Shang are paired together in a relationshipbut that does not strictly define that they are heterosexual. In a recent interview with SNL star Bowen Yang, Li Shang's voice actor-openly gay actor, B.D. Wong—revealed that even back in 1998, he knew Shang was sexually fluid: "When we made the movie, fluidity was not a word. We didn't talk about fluidity. Now we see we watch Shang and his choices and his actions and see it through fluidity" (Wheeler). Whether or not viewers can find the appropriate language to identify these characters, the "queer" disruption caused by their navigation through their respective societies offers a hopeful glimpse at what the future of Disney discourse could be despite its current "bait and switch" narratives.

For Mark Helmsing, the potential for positive representation of queerness in Disney films lies with its villains. "Disney diva villains...teach us the limits of Disney's stifling social logic by unveiling the mechanisms by which these 'evil' characters are forced to survive in a world of social inflexibility... if one identifies with or cheers for the villains, then in part, Disney's intended 
ideological lessons have failed (72-3). For many, the most prominent feature of Disney's villains are the 'over the top,' queer-coded mannerisms they perform as they unveil their evil plans. Historically, Disney's villains have served as a model of behaviors that children should avoid, lest they too wish to meet an unfavorable end. Nevertheless, despite Disney's efforts, it is precisely the theatrical nature of its villains which transform their nefarious deeds and lipstick-stained smirks into beloved traits for audience members that are eager to break away from the princessly molds of its past.

A villain is only positioned as such until they receive the love and empathy of others, then they become a sympathetic person. Elsa is a prime example of this. In the original script for Frozen, Elsa was the film's antagonist until screenwriters heard her anathematic song, "Let It Go," and rewrote her character as a tragic hero. For many, the song's lyrics suggest a readably subtle queerness that has transformed Elsa into a symbol of hope for the gay community. For fans like Cole Reilly, the song serves as "a torch song for "coming out' in any number of ways." He writes, "Elsa decided to no longer conceal this part of her, but to embrace it instead. This facet of her, which she was told was horrible, dangerous even, can finally be appreciated as beautiful, special, liberating. Whatever the metaphor, the song rejects notions of shame to celebrate self-love and empowerment" (62). Indeed, the readably queer undertones interwoven within the song's lyrics suggest a desire on behalf of Disney to embrace more positive examples of LGBTQ representation within its narratives.

Still, one cannot ignore the studio's continuation of subverting such progressive metaphors in favor of upholding the traditional heterosexual conventions that have built its namesake. The most recent example of this trend occurs in Frozen II (2019) as Disney's ostensible resistance to queerness transforms Elsa into the "Snow Spirit"- the protector of a magical forest hidden on the 
outskirts of Arendelle. Like Friend Owl in Bambi's forest, Elsa becomes the "overseer" of society, serving as an "unnatural' guardian over its "natural" forest and the transgressions of its ideologies. Anna and Kristoff - the 'film-appointed lovers' and heterosexual role models of the Frozen franchise-become the new King and Queen of Arendelle following Elsa's departure into the forest. Their coronation thus symbolizes the official return of the father's Law to the kingdom: they will perform within the heterosexual matrix of society, and more importantly, demonstrate Disney's traditional, conservative ideologies through their marriage and the children they will produce. Where Elsa "failed" as Queen—and in essence—as a Disney heroine, Anna will take over and do the "next right thing" to keep the kingdom running for the people of Arendelle.

But what exactly does this mean in terms of Disney's ever-present desire to prove itself as a "progressively inclusive" corporation? For fans of the LGBTQ community, it comes down to a simple request: proper representation. As M. Rogers states in her essay, "Is Disney frozen in time, or moving forward?":

[Elsa] may very well be the queer icon that many of us NEED right now...but ultimately, [she] isn't the queer icon we DESERVE. Her queerness is simply an interpretation, a reading built on metaphor and subtext. She is not canonically queer. She does not give visibility and representation to the LGBTQIAP+ community. What we DESERVE is a queer heroine whose queerness is more than subtext...[and] Elsa isn't that. (Feminist Disney)

Disney has been playing a game of cat and mouse with the LGBTQ community for decades. Audience members continue to paw at the promise of proper representation in Disney's films as the studio continues to keep such dreams just out of reach; promising what we desire but never fulfilling it. The live-action Beauty and the Beast (2017) caused significant controversy when 
rumors of a kiss between two male characters appeared in a scene, only for the actual scene to only last a few seconds and played off their encounter as a "joke." When advertisements for Frozen II began circulating, fans flooded the internet with demands and petitions for Elsa to have a girlfriend. Sadly, this was never brought to fruition as Elsa's romantic narrative was cast aside in favor of Anna and Kristoff's wedding.

After over ninety years of multimedia successes, slight progress is not good enough. Subtly-hinted queer characters continue to appear throughout contemporary Disney films, but these types of half-hearted representations will never satisfy the desires of emerging audiences. Until Disney can commit to an openly gay prince or princess, such representation will continue to be a young child's wish —one that, for now, will have to remain in the castle's closet until a caring mouse knocks on the door. 


\section{Works Cited}

Alexander, Johnathan. Literacy, Sexuality, Pedagogy: Theory and Practice for Composition Studies. University Press of Colorado, 2008. JSTOR, www.jstor/stable/j.ctt4cgqkw.

Aronstein, Susan L., and Laurie A. Finke. "Discipline and Pleasure: The Pedagogical Work of Disneyland." Educational Philosophy \& Theory, vol. 45, no. 6, June 2013, pp. 610-24. EBSCOhost, doi:10.1080/00131857.2012.723885.

Bambi. Dir. James Algar and Samuel Armstrong, Walt Disney Productions, 1942.

Bandura, Albert. "Social Cognitive Theory: An Agentic Perspective.” Annual Review of Psychology, vol. 52, no. 1, 2001, pp. 1-26.

Barron, T.A. "The Unquenchable Source: Finding a Heroic Girl Inside a Man.” Beauty, Brains, and Brawn: The Construction of Gender in Children's Literature, edited by Susan S. Lehr, Heinemann, 2001, pp. 30-5.

Beauty and the Beast. Dir. Gary Trousdale and Kirk Wise, Walt Disney Pictures, 1991.

Beauty and the Beast. Dir. Bill Condon, performances by Emma Watson, Dan Stevens, Luke Evans, and Josh Gad, Walt Disney Studios Motion Pictures, 2017.

Bell, Elizabeth, Lynda Haas, and Laura Sells. From Mouse to Mermaid: the Politics of Film, Gender, and Culture. Indiana University Press, 2012.

Best, J., and K. Lowney. "The Disadvantage of a Good Reputation: Disney as a Target for Social Problems Claims.” Sociological Quarterly, vol. 50, 2009, pp. 431-49.

Brave. Dir. Mark Andrews and Brenda Chapman. Walt Disney Studios Motion Pictures, 2012. Brocklebank, Lisa. 'Disney’s 'Mulan'—-the 'True' Deconstructed Heroine?.” Marvels \& Tales, vol. 14, no. 2, 2000, pp. 268-83. JSTOR, www.jstor.org/stable/41388562.

Butler, Judith. Gender Trouble: Feminism and the Subversion of Identity. Routledge, 1990. 
---. "Imitation and Gender Insubordination." Literary Theory: An Anthology, edited by Julie Rivkin and Michael Ryan, Third ed., John Wiley \& Sons, 2017, pp. 956-62.

---. "Performative Acts and Gender Constitution." Literary Theory: An Anthology, edited by Julie Rivkin and Michael Ryan, Second ed., Blackwell Publishing Inc., 2004, pp.900-11. Chang, Margaret. “Are Authors Rewriting Folklore in Today's Image?.” Beauty, Brains, and Brawn: The Construction of Gender in Children's Literature, edited by Susan S. Lehr, Heinemann, 2001, pp.79-87.

Cheu, Johnson. Diversity in Disney Films: Critical Essays on Race, Ethnicity, Gender, Sexuality, and Disability. McFarland \& Company Inc. Publishers, 2013.

De Cordova, Richard. “The Mickey in Macy's Window: Childhood, Consumerism, and Disney Animation.” Disney Discourse: Producing the Magic Kingdom, edited by Eric Smoodin, Routledge, 1994, pp. 203-13.

England, D. E, L. Descartes, and M. Collier-Meek. "Gender Role Portrayal and the Disney Princesses." Sex Roles, vol. 64, no. 8, 2011, pp. 555-67. http://dx.doi.org/10.1007/s1199011-9930-7.

Frozen. Dir. Chris Buck and Jennifer Lee, Walt Disney Studios Motion Pictures, 2013.

Frozen II. Dir. Chris Buck and Jennifer Lee, Walt Disney Studios Motion Pictures, 2019.

Garber, M. Vested Interests: Cross-dressing and Cultural Anxiety. New York, NY: Routledge, 1992.

Gabler, Neal. Walt Disney: The Triumph of the American Imagination. New York: Vintage, 2007.

Greenhill, Pauline. “The Snow Queen: Queer Coding in Male Directors' Films.” Marvels \& Tales, vol. 29, no. 1, 2015, pp.110-34. JSTOR, www.jstor.org/stable/10.13110/marvel 
stales.29.1.0110.

Giroux, Henry A. "Memory and Pedagogy in the "Wonderful World of Disney"." From Mouse to Mermaid: the Politics of Film, Gender, and Culture, edited by Elizabeth Bell, Lynda Haas, and Laura Sells, Indiana University Press, 2012, pp. 43-61.

Giroux, Henry A., and Grace Pollock. The Mouse That Roared: Disney and the End of Innocence. Plymouth: Rowman \& Littlefield, 2010.

Griffin, Sean. Tinkerbelles and Evil Queens: The Walt Disney Company from the Inside Out. New York University Press, 2000.

Grimm, Jacob, et al. Grimm's Fairytales. Barnes \& Noble Classics, 2003.

Halberstam, Judith. The Queer Art of Failure. Duke University Press, 2011.

Heilmann, Ann. “(Un)Masking Desire: Cross-Dressing and the Crisis of Gender in New Woman Fiction.” Journal of Victorian Culture, vol. 5, no.1, 2000, pp. 83-111.

Helmsing, Mark. "This Is No Ordinary Apple!: Learning to Fail Spectacularly from the Queer Pedagogies of Disney's Diva Villains.” Disney, Culture, and Curriculum, edited by Jennifer A. Sandlin and Julie C. Garlen, Routledge, 2016, pp. 89-102.

Hewes, Jane, et al. “Unfreezing Disney's Frozen through Playful and International CoAuthoring/ Co-Playing." Canadian Journal of Education/ Revue Canadienne De L'éducation, vol. 39, no. 3, 2016, pp. 1-25. JSTOR, www.jstor.org/stable/canaj educrevucan.39.3.10.

Hine, B., D. England, K. Lopreore, E.S. Horgan, and L. Hartwell. "The Rise of the Androgynous Princess: Examining Representations of Gender in Prince and Princess Characters of Disney Movies Released 2009-2016.” Social Sciences, vol. 7, no. 12, 2018, pp. 245-63. Huck, Charlotte S. "Introduction." Beauty, Brains, and Brawn: The Construction of Gender in 
Children's Literature, edited by Susan S. Lehr, Heinemann, 2001, pp. vii- xi.

Hutcheon, Linda, and Siobhan O' Flynn. A Theory of Adaptation. Second ed., Routledge, 2013. Key, Adam. “A Girl Worth Fighting For: A Rhetorical Critique of Disney Princess Mulan's Bisexuality." Journal of Bisexuality, vol. 15, no. 2, 2015, pp. 268-86.

Kornfield, Sarah. "Cross-Cultural Cross-Dressing: Japanese Graphic Novels Perform Gender in U.S.” Critical Studies in Media Communication, vol. 28, no. 3, Aug. 2011, pp. 213-29. Lacan, Jacques. "The Mirror Stage as Formative of the Function of the I as Revealed in Psychoanalytic Experience." Literary Theory: An Anthology, edited by Julie Rivkin and Michael Ryan, Third ed., John Wiley \& Sons, 2017, pp. 618-23.

Lang, Nico. “Disney's Long Complicated History with Queer Characters.” Harper's Bazaar, Hearst Magazine Media, Inc., 10 April 2018, www.harpersbazaar.com/culture/filmtv/news/a21506/disney-gay-lgbt-characters-history/.

Law, Michelle. "Getting Down To Business: Mulan and Disney's Evolving Progressivism." Screen Education, no. 91, Oct. 2018, pp. 16-21. EBSCOhost, search.Ebscohost.com /login.aspx ?direct=true \&db=ufh\&AN=131888158\&site=ehost-live.

---. "Sisters Doin' it for Themselves: Frozen and the Evolution of the Disney Heroine." Screen Education, vol. 74, 2014, pp. 16-25.

Letts, Will. "Camp: Disney: Consuming Queer Sensibilities, Commodifying the Normative." Disney, Culture, and Curriculum, edited by Jennifer A. Sandlin and Julie C. Garlen, Routledge, 2016, pp. 148-61.

Limbach, Gwendolyn. "You the Man, Well, Sorta": Gender Binaries and Liminality in Mulan." Diversity in Disney Films: Critical Essays on Race, Ethnicity, Gender, Sexuality, and Disability, by Johnson Cheu, McFarland \& Company Inc. Publishers, 2013, pp. 115-28. 
The Lion King. Dir. Roger Allers and Rob Minkoff, Walt Disney Pictures, 1994.

The Lion King. Dir. John Favreau, performances by Donald Glover, Seth Rogen, Chiwetel

Ejiofor, Alfre Woodard, and James Earl Jones, Walt Disney Studios Motion Pictures, 2019.

The Little Mermaid. Dir. Ron Clements and John Musker, Walt Disney Pictures, 1989.

Louie, Belinda Y. "Why Gender Stereotypes Still Persist in Contemporary Children's

Literature." Beauty, Brains, and Brawn: The Construction of Gender in Children's Literature, edited by Susan S. Lehr, Heinemann, 2001, pp. 142-51.

Lutts, Ralph H. “The Trouble with Bambi: Walt Disney's Bambi and the American Vision of Nature." Forest \& Conservation History, vol. 36, no. 4, 1992, pp. 160-71. JSTOR, www.jstor.org/stable/3983677.

Mickey Mouse Monopoly. By Chyng Feng Sun. Dir. Miguel Picker, Media Education Foundation. Web. 20 Dec. 2019.

Mulan. Dir. Tony Bancroft and Barry Cook, Walt Disney Pictures, 1998.

Munns, David P. D. “Gay, Innocent, and Heartless': Peter Pan and the Queering of Popular Culture." Second Star to the Right: Peter Pan in the Popular Imagination, edited by Allison B. Kavey and Lester D. Friedman, Rutgers University Press, 2009, pp. 219-42. EBSCOhost,$\quad$ search.ebscohost.com/login.aspx?direct=true\&db=mlf\&AN=20096 40772\&site=ehost=live.

Newall, Venetia. "Folklore and Male Homosexuality." Folklore, vol. 97, no. 2, 1986, pp. 123-47. JSTOR, www.jstor.org/stable/1259523.

Orenstein, Peggy, Cinderella Ate My Daughter: Dispatches from the Front Lines of the New Girlie-Girl Culture. HarperCollins, 2013.

Rabaté, Jean-Michel. The Cambridge Companion to Lacan. Cambridge University Press, 2003. 
Reilly, Cole. "An Encouraging Evolution Among the Disney Princesses? A Critical Feminist Analysis." Counterpoints, vol. 477, 2016, pp. 51-63. JSTOR, www.jstor.org/stable/45 157186.

Rich, Adrienne. "Compulsory Heterosexuality and the Lesbian Experience." Literary Theory: An Anthology, edited by Julie Rivkin and Michael Ryan, Third ed., John Wiley \& Sons, 2017, pp. 925-39.

Rogers, M. “Is Disney frozen in time, or moving forward?" Feminist Disney, 2014. Available at https://feministdisney.tumblr.com/post/72728984022/is-disney-frozen-in-time-ormoving-forward

Padilla-Walker, Laura M, et al. "Is Disney the Happiest Place on Earth?: A Content Analysis of Prosocial Behavior in Animated Disney Films." Journal of Communication, vol. 63, no. 2, 2013, pp. 393- 412. Communication and Mass Media Complete, Web.

Payne, David. "Bambi." From Mouse to Mermaid: the Politics of Film, Gender, and Culture, edited by Elizabeth Bell, Lynda Haas, and Laura Sells, Indiana University Press, 2012, pp. $137-47$.

Peter Pan. Dir. Clyde Geronimi and Wilfred Jackson, Walt Disney Productions, 1953.

Pocahontas. Dir. Mike Gabriel and Eric Goldberg. Buena Vista Distribution, 1995.

Putnam, Amanda. "Mean Ladies: Transgendered Villains in Disney Films." Diversity in Disney Films: Critical Essays on Race, Ethnicity, Gender, Sexuality, and Disability, by Johnson Cheu, McFarland \& Company Inc. Publishers, 2013, pp. 147-62.

Sedgewick, Eve Kosofsky. "The Epistemology of the Closet." Literary Theory: An Anthology, edited by Julie Rivkin and Michael Ryan, Third ed., John Wiley \& Sons, 2017, pp. 1014-23. 
Snow White and the Seven Dwarfs. Dir. William Cottrell and David Hand, Walt Disney Productions, 1937.

Spencer, Leland G. "Performing Transgender Identity in The Little Mermaid: From Anderson to Disney." Communication Studies, vol. 65, no. 1, Jan. 2014, pp. 112-27. EBSCOhost, doi:10.1080/10510974.2013.832691.

Streiff, Madeline, and Lauren Dundes. "Frozen in Time: How Disney Gender-Stereotypes Its Most Powerful Princess.” Social Sciences, vol. 6, no. 2, 2017, pp. 38-48, doi:10.3390 /sosci6020038.

Sweeny, Gael. "What Do You Want Me To Do? Dress in Drag and Do the Hula?": Timon and Pumbaa's Alternative Lifestyle Dilemma in The Lion King." Diversity in Disney Films: Critical Essays on Race, Ethnicity, Gender, Sexuality, and Disability, by Johnson Cheu, McFarland \& Company Inc. Publishers, 2013, pp. 129-146.

Tatar, Maria. The Classic Fairy Tales. New York: W. W. Norton \& Co., 1999.

Thinking Straight: The Power, Promise, and Paradox of Heterosexuality, edited by Chrys Ingraham, Routledge, 2004. ProQuest Ebook Central, https://ebookcentral.proq uest .com/lib/ric-ebooks/detail.action?docID=201229.

Wallace, David L., and Johnathan Alexander. "Queer Rhetorical Agency: Questioning Narratives of Heteronormativity.” JAC, vol. 29, no. 4, 2009, pp. 793-819. JSTOR, www.jstor.org /stable /20866924.

Wheeler, Andrea. "Mulan's Love Interest Was ‘Sexually Fluid," Says BD Wong.” Them., Them., 19 Mar. 2021, www.them.us/story/disney-mulan-li-shang-sexually-fluid-bd-wong.

Wohlwend, Karen E. “The Boys Who Would Be Princesses: Playing with Gender Identity 
Intertexts In Disney Princess Transmedia.” Gender \& Education, vol. 24, no. 6, 2012, pp. 593-610. Academic Search Complete, Web.

Zipes, Jack. "Breaking the Disney Spell." From Mouse to Mermaid: the Politics of Film, Gender, and Culture, edited by Elizabeth Bell, Lynda Haas, and Laura Sells, Indiana University Press, 2012, pp. 21-42.

---. The Irresistible Fairy Tale: The Cultural and Social History of a Genre. Princeton University Press, 2013.

Žižek, Slavoj. How to Read Lacan. W.W. Norton \& Co., 2007.

Zornado, Joseph L. Disney and the Dialectic of Desire: Fantasy as Social Practice. Palgrave Macmillan, 2017. 